\title{
On the interplay between tense marking, aspect and temporal continuity in Udora Komi
}

The Udora dialect of Zyrian Komi lacks the morphological opposition between the present and future tenses that is found in other Komi dialects and the written standard. The morphemes corresponding to these tenses are, however, found in this dialect, with individual verbs showing a strong tendency to choose one of the two. This study shows that the two morphemes are not in free variation but rather carry various grammatical meanings, and that the variants are strongly connected to the lexical aspect of individual verbs.

Due to the rigidity of the system, the authors refer to the variants here as conjugation types. The -as-conjugation type, which corresponds to the Standard Komi future marker, occurs with all transitive verbs and a majority of intransitive verbs. However, the study also identifies a group of intransitive verbs occurring with the conjugation type - - - The verbs in the latter group can be analysed as temporally continuous. Additionally, there are other subgroupings that can be postulated, including verbs that describe involuntary actions. The system interacts in a predictable manner with Komi derivational morphology.

The study also corroborates the previously proposed historical connection between this characteristic of verbal morphology in the Udora dialect and Old Komi. The authors suggest that the verbal morphology seen in these Komi varieties must predate the contemporary tense system. The study provides a new direction for analysing the development of the tense system in the Permic languages, as it is shown that the factors underlying the variation extend beyond transitivity. As a previously undescribed phenomenon, the study describes the use of the Udora conjugation types in narrative tense structuring and demonstrates parallels with Standard Komi.

1. Introduction

2. Related work

3. Background

3.1. Udora within the Komi dialects

3.2. Third-person tense marking in Komi

4. Data

5. Analysis

5.1. Distinct tense markers as two conjugation types in Udora

5.2. Correlation with transitivity

5.3. Aspect and temporal continuity

5.4. Derivations and conjugation classes

5.5. The narrative use of tense markers in the Udora dialect

5.6. Comparison to Old Komi

6. Conclusion 


\section{Introduction}

The Udora dialect is a variety of the Zyrian Komi ${ }^{1}$ language that is spoken in the westernmost corner of the Komi speaking area. In this region, Komi villages follow two large rivers, the Vaška and the Mezen. Geographically speaking, the area is relatively remote. The Udora region has 21 settlements that are included in the population censuses, but these can usually be divided into smaller local clusters of villages. According to the Russian population census conducted in 2010, there were 8,018 Komi living in the Udora region, comprising 40 percent of the region's population (Federal State Statistics Service, Russia 2010). There is no recent sociolinguistic research on the situation with regard to language maintenance in the region. Based on the authors' fieldwork experience, the traditional Komi villages in the area are largely Komi-speaking, but the younger inhabitants regularly move to larger cities, which has an impact on their language use. The official population statistics for the region paint a picture where approximately 75 percent of the inhabitants of the smaller villages, which include Glotovo, Koslan, Ćernut'evo, Ćuprovo, Pučkoma, Pyssa, Važgort and Jortom, are Komi-speaking (Federal State Statistics Service, Russia 2010). As such, the dialect has numerous unique features at all levels of language. Morphologically, the Udora dialect does not distinguish between the present and future tenses, which is unusual among the Permic languages and dialects.

In this study, we aim to describe the third-person verb marking in Udora and the functions of two distinct morphemes that are in variation. We propose that the use of these morphemes is lexically conditioned and connected to a lexical aspect system, so that intransitive, temporally continuous verbs receive a distinct morphological marking. The traditional description of this feature states that the Udora dialect employs formally identical (i.e. syncretic) present-tense and future-tense markers, but the temporal distinction between them is blurred (see Sorvačeva \& Beznosikova 1990: 67; Lytkin 1961: 52-53; 1977a: 282; Cypanov 2005: 28, 141, 147).

1. Throughout the study, we use the terms Zyrian Komi and Permian Komi to refer to the two main Komi varieties and written standards. We find that this convention fits well with the terms Зыран-Коми and Перым-Коми used in Komi scientific research. The terms Komi-Zyrian, Komi-Permyak and Perm Komi can certainly also be used, and we do not consider the English conventions for referring to these languages to have fully emerged yet. 
Following this pattern, a Udora dialect speaker would customarily inquire about the identity of a new person by asking:

(1) Кудз тэнӧ шуасны?

kuź tene šu-asni

how 2SG.ACC say-FUT.3PL

'What's your name? (lit. How will they call you?)'

(Authors' field notes)

In Standard Komi, and to our knowledge in all other dialects, the idiomatic expression would almost without exception contain the present tense verb form шуӧны /šueni/ 'they say', as the speaker's motive is to find out how someone is called at the moment so they will know how to refer to them. Of course, given the right context, the future form could also occur, as seen in (2). We note that the writer of this text, Aleksandr Matveev, was born in the Syktyvdin region:

(2) Бӧбӧн тэнӧ шуасны, Владимир, татшӧм ныв вылӧ кӧ он гӧтрась! begb-ęn tene šu-asni, vlad'imir, tačęm niv fool-INS 2SG.ACC say-FUT.3PL Vladimir this_kind girl vil-e ke on getraś on-ILL if NEG.2SG marry.CNG

'You will be called an idiot, Vladimir, if you don't marry a girl like that!' (Matveev 1958: 48)

In examples such as this one, however, there is often a clear temporal or sequential interpretation. In fact, getting married in the future is the topic of the humorous play from which this example originates. Cypanov (2005: 148) characterises the Komi future tense as being used when the event described event after the moment of speech, in a one-time process that cannot be divided into phases, and with modal connotations about the certainty of the outcome. This is exactly what we see here. Most of the play is in the present tense, but there are a few instances where the future tense is used. We will use another example from the same play to illustrate the Standard Komi use of the present and future in Section 3.2.

The system we find in Udora is strikingly different, with verbs marked with -as- in the third person being the most common, and with - $e$ - marking occurring with individual verbs. We see this in (3) and (4). 
(3) Иван чаревич водас и унмовсяс. И узьӧ куим сутки. Сы дінӧ воасны став зверыс, коді тэсі вӧйтча.

ivan tsarević vod-as i unmovś-as. $i$

ivan tsarevich lie_down-FUT.3Sg and fall_asleep-FUt.3SG and

uź-e kujim sutki. si din-e vo-asni

sleep-PRs.3SG three day.PL 3SG at-ILL come-FUT.3PL

stav źver-is, kodi tes-i vejćća.

all animal-3sg who meet-PST.3Sg before

'Ivan Tsarevich lies down and falls asleep. And he sleeps for three days. All the animals he has met come to him.' (Fokos-Fuchs 1916: 160)

(4) Ӧти идзас-бынмӧд пыртас и мӧдла петӧ, а купечъес повзясны и пышйӧны ӧти дӧрӧм кежӧ.

ęt'i iźas-binm-ẹd pirt-as i medla

one straw-bunch-PROL take_in-FUT.3SG and elsewhere

pet-e, a kupeć-jes povź-asni i

go_out-PRS.3SG but merchant-PL frighten-FUT.3PL and

pišj-ęni ęt $i$ derem kež-e.

escape-PRS.3PL one shirt middle-ILL

'He takes in a stack of straw and goes out. But the merchants are frightened and run into a thread shirt.' (Fokos-Fuchs 1916: 172)

In these examples, the majority of verbs are marked with what in Standard Komi would be the future tense, but individual verbs such as 'sleep', 'go out' and 'escape' are in the present tense. It seems clear to us that, in examples such as these, the intended function cannot be tense marking. There is, however, an underlying systematicity, and that is what we aim to describe.

Our study is structured so that we first discuss the position of Udora within the Komi dialects. From this, we move into a more general description of how the use of the present and future tenses is described in contemporary Komi grammar. After this, we discuss the dataset used for our study. In our analysis, we examine different features and hypotheses that have been connected to the Udora third-person verb forms in earlier literature: object conjugation (Lytkin 1977a: 283) and transitivity (for the transitivity and object conjugation hypothesis, see also Serebrennikov 1956: 68), imperfect aspect especially with specific derivations (Serebrennikov 1963: 255) and derivation types in general (Sorvačeva 1952: 46; Ponarjadov 2004: 112). We complement this analysis with an external comparison to 
Old Komi, where similar variation to that found in the Udora dialect has been described before (Lytkin 1977a: 282; Cypanov 2005: 30). This external comparison serves to root our results in their historical context within Komi dialectology. We also examine and discuss our novel observation that the morphemes under investigation are used in the Udora dialect as a way to mark event structure in narratives. In that section, we provide a large number of complete example texts that also illustrate the use of tense in the Udora dialect more broadly.

The examples in this study are presented in the contemporary Komi orthography, with morphemic interlinearisation in Finno-Ugric Transcription and glosses in English. For the sake of clarity, we use the abbreviations PRS and FUT in our interlinear glosses to mark the verb forms under investigation, although these are not unproblematic labels for glossing occurrences of these forms in the Udora dialect. The level of transcription is phonemic, and examples taken from different sources have been harmonised into a comparable representation. The relevant third-person verb forms are marked in bold. For the original versions of the transcriptions, we encourage the reader to consult the works cited. All translations have also been revised and edited by the authors, and are not identical to those found in the original sources. Whenever numeric results are discussed, the observations obtained from our corpus are presented as contingency tables. We have also published the individual example dataset as an online appendix to the current study (https://doi.org/10.33339/fuf.97371) so that our results can be compared with different materials and to facilitate further work.

\section{Related work}

There have been several individual studies connected to Udora verbal morphology, but the examples from Udora are usually used to illustrate a broader argument, especially in the context of historical morphology. Studies that exclusively investigate the Udora dialect have remained rare. The earliest modern description of the Udora dialect is by Sidorov (1930), who does not discuss the behaviour of the present and future markers among the particularities of the dialect. A few decades later, Sorvačeva (1952) provides a more detailed treatment, which also addresses Udora verbal morphology. In her view, reflexive verbs formed with $s$ and verbs of action and movement employ the -e - conjugation (Sorvačeva 1952: 46). She argues that at Upper Vaška, aspectual differences are marked as in Russian 
(Sorvačeva 1952: 44). This idea is later supported by Serebrennikov (1963: 255) in connection with past-tense allomorphy in Udora, but it is rejected by Cypanov (2005: 87), who do not see this analysis as being supported by contemporary data. This mainly illustrates that the notion of aspect has been regularly present in discussions of the Udora dialect. We suggest in our study that aspect is a relevant category behind the variation in Udora, but this is primarily in the sense of lexical aspect, which is a viewpoint that has not been previously suggested.

The most important description of the Udora dialect is arguably the monograph by Sorvačeva and Beznosikova (1990). In it, they describe a non-differentiated present-future tense and state that the morphemes are used interchangeably (Sorvačeva \& Beznosikova 1990: 68). The variation is not further explained, but the authors refer to Lytkin's explanation about the different stem vowels being reflected in the two endings (Sorvačeva \& Beznosikova 1990: 67). Here, the argument is that the -s- would be a separate element that was added due to homonymy with other persons in the past tense (Lytkin 1961). Synchronically, the monograph does not offer more details about the use of these tense marking morphemes, but it is still the most thorough description of this dialect.

Lytkin (1961: 53-54) compares the conjugation systems in the Udora dialect and Mari, arguing that the systems are similar, and agrees with the early analysis of Sorvačeva (1952: 46) in that action and movement verbs and specific derivations are connected. He argues, however, that this does not explain the whole picture and that verbs cannot be categorised into only these groups in the contemporary Udora dialect. Lytkin (1961: 54) states that defining the exact parameters for the variation is not possible. Somewhat later, Lytkin (1969: 97) also connects the Udora conjugations to historical stem vowels, eventually extending the comparison to other Uralic languages.

The connection to Old Komi was also recognised at an early stage: Lytkin (1977a: 63-64) proposes that in Old Komi, the present and future tense were not distinguished, and that the same phenomenon is in some manner visible in the Udora dialect. Lytkin (1977b: 280, 283) connects the Zyrian Komi past tense allomorphy to the present-future variation in Udora, and also discusses it in the context of Old Komi. The development Lytkin proposes is that object conjugation was in the process of developing in Komi but never became fully established. ${ }^{2}$ This underdeveloped object conjugation was an-

2. In Lytkin's words: не пустило глубоких корней. 
alysed in the rest of the Komi speaking area as a present-future opposition, but has left various traces, especially in the Udora dialect (Lytkin 1977a: 283). The suggested development is that the forms marked with $-s$ - used to express transitivity, and that the function of future tense emerged from this. Later, the use of this element also spread to intransitive verbs (Lytkin 1977a: 282-283; Bartens 2000: 191). Similarly, Cypanov (2005: 141) analyses the undifferentiated present-future marking in Udora as an archaism, where the functions of the - $e$ - and -as- morphemes were not yet entirely separate, but he does not find the historical scenario proposed above entirely convincing. The idea that Proto-Permic would not have had distinct present and future tenses is further complicated by the fact that, with the exception of the Udora dialect, the Permic varieties have been described as having remarkably similar present-future tense systems, with an essentially identical set of two morphemes, as has also been noted by Ponarjadov (2004: 106).

The study by Ponarjadov (2004) is one of the few recent studies that focuses only on Udora materials. His approach is etymological, and his results support Lytkin's idea that the two morphemes are selected by individual verbs (Ponarjadov 2004: 108). He further connects this to the different reconstructed stem vowels, and concludes that it is not possible to find a temporal distinction between these morphemes in the Udora dialect. In Section 5.5, we do report a distinctive usage in narratives that, to our knowledge, has not been described before. Ponarjadov (2004: 110-111) also finds that derivational morphology impacts the choice of morphemes but states that the reasons for this are unclear. Our analysis in Section 5.4 shows that the process in Udora is connected to the properties of different derivations, depending essentially on the semantics of individual verbs. The analysis of Ponarjadov (2004), especially with regard to derivations, is an important predecessor to our current work. We do not, however, examine the reconstructed stem vowels in more detail, primarily because this would require a very extensive investigation of the latest etymological literature, which is beyond the scope of this study. We hope, however, that our word lists and results will also be useful for further research in this direction. The most current research on Uralic historical morphology also suggests that we cannot reconstruct the Proto-Uralic tense system very well, and there are various conflicting possibilities as to how it could be reconstructed (Aikio, forthcoming).

The connection between these forms and object conjugation is, according to Csúcs (2005: 260), the generally accepted opinion of the field, and he discusses it in connection with a similar analysis by Rédei (1989: 199). 
The diversity of opinions in the field, the complexity of the issue and our evolving understanding of the earlier language stages suggest that more research is needed.

In this study, we do not attempt to propose alternative developments, but rather try to analyse the phenomenon primarily on a synchronic level using attested language forms as our sources. It seems to us that earlier work on this topic has often proceeded in a bottom-up fashion, where the current state of the art in historical linguistics has been used to reason and explain the variation we see today in these language varieties. In our view, however, we should emphasise the best possible contemporary description, which should then impact the possible reconstructions.

\section{Background}

\section{I. Udora within the Komi dialects}

Zyrian Komi is traditionally described as having ten dialects. The written standard is based on the dialect from the Syktyvkar region, which is spoken at the boundary of two major dialect groups. Zyrian dialects are commonly divided into the Northern and Southern groups, with the dialects of Udora, Lower Vyčegda, Vym and Ižma belonging to the Northern (also known as North-Western) group (Popova \& Sažina 2014: 8). There is also a history of connecting the North-Western dialects to Old Komi (Lytkin 1977a: 282), with which Udora shares other isoglosses (Popova \& Sažina 2014: 103). These varieties appear to belong to the same historical dialect group (Ljašev 1980: 12). Lytkin (1952: 121) has also analysed Udora, Vym and Old Komi as belonging to the same dialect group and as having minor differences from one another, in contrast to the clearer difference they have from the Sysola dialects. For a thorough overview of Komi dialects, see Popova and Sažina (2014) and the monographs on individual dialects. A thorough review is beyond the scope of this paper, but it is worth noting that Udora exhibits a variety of features that do not have parallels in any other Komi dialect; for further details, see Sidorov (1930) and Sorvačeva (1952). At the same time, Vym and Ižma have features not shared with Udora, such as dative object marking (Klumpp 2008: 189; Ljašev 1977: 120), which would indeed support the idea, presented in Figure 1a, that Ižma would historically descend mostly from Vym and not from Udora. 
Tense and aspect in Udora Komi
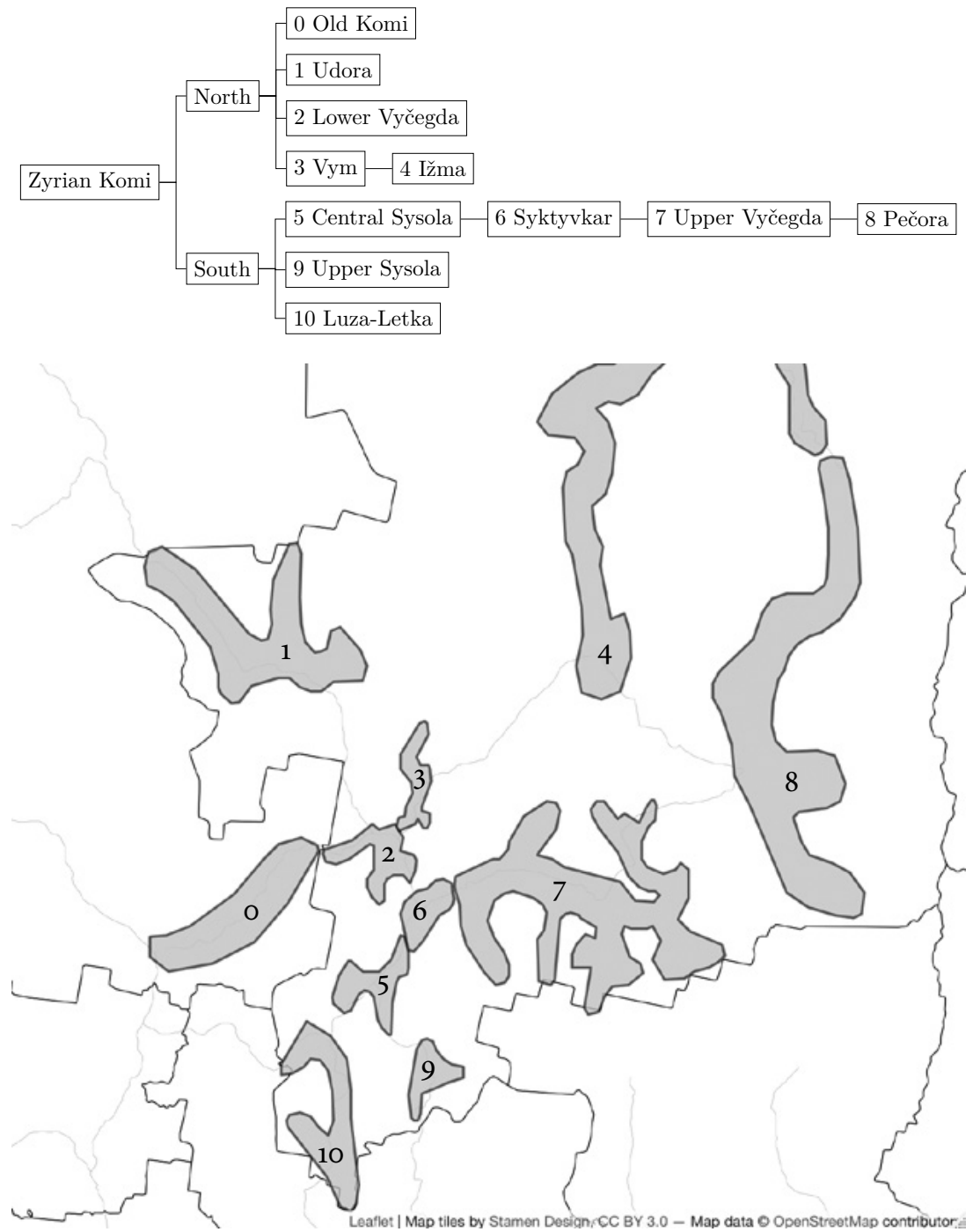

Figure 1: Tree (1a) and map (1b) of Zyrian Komi dialects

According to Sažina (2014: 82), there are six modern Zyrian Komi dialects that can be regarded as continuations of the earliest dispersal of Komi to its current speaking area. These are the Southern Zyrian dialects of LuzaLetka, Upper Sysola and Central Sysola, and the Northern Zyrian dialects of Vym, Lower Vyčegda and Udora. These are also the areas where Zyrian 
settlements could already be found by the 15th century (Savel'eva 1997: 55, 61). These oldest dialects are marked in Figure 1a at the lowest level in the Zyrian dialect hierarchy with the extinct Old Komi. The other varieties, although relatively old, represent later areal expansions.

From the perspective of our study, the most central implication of the historical background of the Zyrian dialects is that Udora is among the oldest dialects, and none of the other dialects descend directly or solely from it, nor can we postulate any of the modern dialects to be its predecessor. Therefore, if a unique feature is described in the Udora dialect, even if it cannot be found in other modern Komi dialects, we cannot conclusively demonstrate that the development must be a Udora innovation. When we discuss a feature that occurs within the Permic languages in only one dialect, the historical relations of the dialects are central to what can be postulated.

From the point of view of population history, we can also take into account the suggestion of Žerebcov (1972) that Udora was populated from the south, which is the area where Old Komi was spoken (see Figure 1b). The Yarenga area, located to the south of Udora, was once Komi-speaking, and there were migrations to the Vaška area in the 1400 o before the local language shift was complete and the areas in the south became Russianspeaking (Žerebcov 1972: 19). The earlier Komi presence in these regions, including the Pinega Basin, is also clear from toponymic evidence (Turkin 1984: 178). Vaška was populated first, and permanent settlements at Mezen appeared in the second half of the 16th century, but there were also migrations to Mezen from parts of Vym (Žerebcov 1972: 21-22). This supports the description of Sidorov (1930: 49), who states that the Udora subdialects differ such that Vaška is more similar to Lower Vyčegda and Mezen closer to Vym.

\subsection{Third-person tense marking in Komi}

Komi has an elaborated tense system with various functionally differentiated forms. The morphologically marked tenses are two past tenses, present and future. The rest of the tenses are constructed using auxiliaries and participles, and the second past tense also originates from a participle. The second past tense has additional meanings connected to evidentiality and indirectivity (Leinonen \& Vilkuna 2000), or to the sense of noninvolvement (Baker 1983: 76). For an analysis of the different functions, see also Cypanov and Leinonen (2009). In the glosses, the second past tense is 
distinguished using the abbreviation PST2, whereas the first past tense is marked with PST. In all Komi dialects, the functional distinction between present and future appears in the inflectional paradigm only in the thirdperson forms. In the first and second person, the forms are identical. In the third person, the distinction is marked with the morpheme -e - in the present tense and -as-in the future tense. Additionally, future meanings can be expressed by means of verbs used in a modal sense, such as кутны /kutni / 'hold', пондыны /pondini / 'begin' or мӧдны /meูdni/ 'go (in a certain direction)' (Popova \& Sažina 2014: 212). These two distinct grammatical strategies for expressing future meanings are customarily referred to in Komi grammaticography as the first and second future tenses, in analogy to the numbered past tenses.

The starting point for our investigation is that, as described in modern grammars, the present and future in third person should be distinguished in the written Zyrian Komi standard as two different tenses. We are not aware of any research that would argue that the main distinction is something else. The most detailed description of the uses of the Komi present and future tenses can be found in the grammar Ӧнія коми кььв (Fedjunëva et al. 2000). According to this grammar, the Komi present tense is used in the following situations (examples taken from Fedjunëva et al. 2000: 239-240) (translation by the authors, examples within text omitted):

1. To express the direct present, i.e. the actual, current moment when the described action is taking place at the exact time of speaking, without moving beyond it.

2. To indicate a reoccurring, abstract present tense, when the moment of speaking is understood widely and the action takes place more than once.

3. To express events that exist at all times and in all possible situations.

4. To indicate the relative, indirect present tense in the past, when the narrator is describing something happening, often in a relative clause introduced by main clause in a different tense.

5. In folklore, speech and literature, one encounters the historical present tense where the verb marks a distant event as if it would be taking place now.

6. To express a "transferred" tense, which is when the present tense is used in a context with another tense and takes on the meaning of that tense, as though the expression should perhaps have been in another tense. 
The same grammar describes the use of the future tense as follows:

1. To express a specified future meaning.

2. To indicate a distant future meaning, which expresses an event that will take place at some unspecified time. [...] This meaning can also be called clearly known future, which will take place in truly unknown time.

3. To express a gnomic, broad future tense meaning, which occurs in proverbs, in fixed phrases, [...] [I]n proverbs, the present tense may also be used, $[\ldots]$ the meaning does not change significantly. The gnomic meaning appears in future forms when the event discussed takes place always or happens from time to time.

4. As a modal future that expresses the speaker's opinion about the topic, how it is valued or evaluated. It was already mentioned that the future tense is used for a clearly known, certain action. [...] Often with this form, the speaker displays their own belief, i.e. the possibility that the thing will happen. This is often used in situations where the speaker expresses their own loss, disbelief or hopelessness.

5. The "transferred" meaning of the future that is used in place of other tenses is very common. Future verbs are used in present and past tense contexts to bring the speaker closer to the events and to make the speech more vivid. [...] The transferred meaning can surface in two contexts: a) with the present tense, and b) with the past tense. When used with the present tense, it expresses continuously happening events that are being discussed. This meaning is particularly common in everyday speech [...]. When used together with the past tense, the future marking expresses things that have happened at some point; it often appears in legends, stories, literature and when recounting memories. Most commonly, the past tense expresses its own base meaning, marking phases in the events that take place in known times.

It is worth noting that there are numerous instances where the present tense and future tense are used in similar contexts to one another. Point 3 in both lists, always ongoing or gnomic events, is very similar for both tenses, and it is even noted that both tenses can be used here interchangeably. Fedjunëva et al. (2000: 237) point out that both the present and the future appear in past-tense narratives as stylistic devices. They also distinguish as one parameter between present and future tense the aspectual difference where the future tense marks events that will be completed (2000: 238). 
The reader may recall that in Section 1, we provided a short example of a typical use of the Komi future tense (see Example 2 above). As can be gleaned from the descriptions in the current section, however, the use of the Komi present and future tenses is much more complicated. To help the reader fully appreciate this complexity, we present here another example from the same play, which was originally published in the journal Войвыв Кодзув in 1958. Example (5) is from the part of the text describing the typical and habitual behaviour of the protagonist Vladimir's mother. No example is perfect, but we believe this one shows many typical properties of Komi tense marking. In the beginning, where the action of hiding is described, the subordinate clause is in the present tense. This fits in with feature 4 in the list of uses of the present tense provided above. At the end of the example, the tense shifts back to the future, which can be compared to feature 5 in the listed uses of the future tense, as it is essentially connected to the stylistic use of the future in the narrative.

(5) Локтасны сы дінӧ, а сійӧ дзебсьӧ. Ӧтчыд ӧти фотокорреспондент топӧдӧма вӧлі, но спаситіс ӧш. Микулай нима. Кыдз тай Микулайыд сюръяснас потолокас лэбӧдас снимайтчан аппаратсӧ!

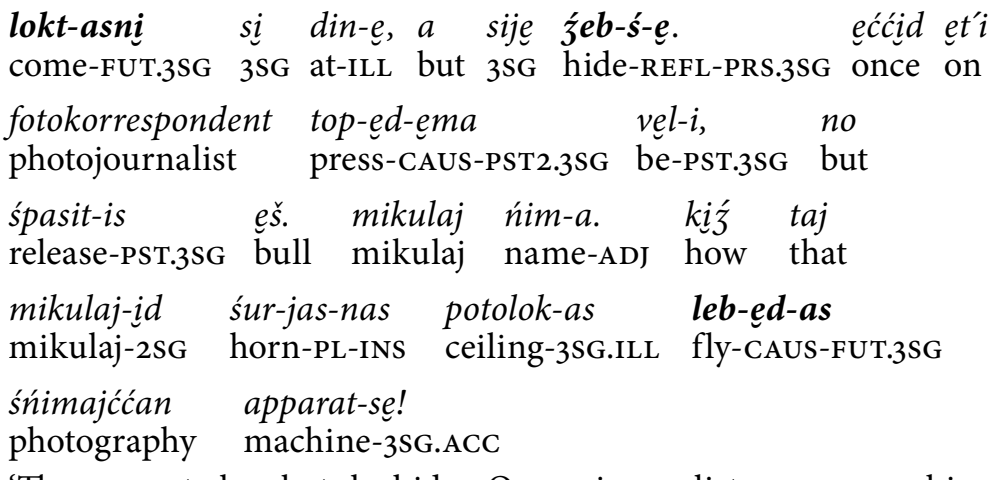

'They come to her, but she hides. Once a journalist was approaching her, and she released a bull. It was called Mikulay. Oh how that Mikulay threw [the journalist's] camera up to the roof with his horns!' (Matveev 1958: 47)

The middle part of (5) employs the second and first past tenses. According to Leinonen and Vilkuna (2000: 501), the second past tense is used in Komi to express a break in the main line of narration, which may be what is happening here. We also encounter such uses in the Udora materials, where the second past tense is followed by a consistent use of a future-marked 
tense. We will discuss this use further in Section 5.5. The reader can also consult Examples (21) and (25), where the second past tense is used in an arguably similar function at the beginning of the narrative to establish or distinguish a certain phase of the text.

Table 1: Komi third-person paradigm with the verb мунны /munni/ 'go', dialectal variation included. The variants accepted in the Zyrian Komi written standard are marked in bold.

\begin{tabular}{lllll}
\hline & Past II & Past I & Present & Future I \\
\hline Singular & mun-em & mun-i & mun-e & mun-as \\
& mun-ema & mun-is & & \\
Plural & mune-maś & mun-i-ni & mun-e-ni & mun-a-ni \\
& mune-maaś & mun-i-nis & mun-e-nis & mun-as-ni \\
& mune-ma-és & mun-is-ni & & mun-as-nis \\
& & mun-is-nis & & \\
\hline
\end{tabular}

When we look at the actual tense marking morphemes, we can see that there is extensive allomorphic variation in Komi dialects. The variants found in different dialects are presented in Table 1. Forms allowed within Standard Zyrian Komi are marked in bold. Our current study focuses on the variation between the present and future forms - $e$ - and - $a s$ - in both singular and plural. Especially the variation in the first past tense is so similar to the variation we see in Udora that one has to ask whether the allomorphs $V s \sim V$ are in variation that is similarly conditioned to what we find in the Udora present-future tenses. This question is beyond the scope of the current study, but it is connected to our research question and illustrates that there are related phenomena concerning various Komi dialects, not only Udora. We will also use the Standard Komi description of these tenses as a point of comparison when we analyse the phenomenon in Udora.

Although the present and future tense are contemporarily described in Komi, their status has not always been clear. In the earlier descriptions, there has been a great deal of variation as to whether the present and future tense are described separately, but contemporary grammars do so (Cypanov 2005: 123-125). Lytkin (1969: 96) also argued that the reason previous researchers, mainly Wiedemann (1884: 116) and Uotila (1938: 54), had analysed the Komi non-past tenses as an undifferentiated present-future tense was that the Komi future is frequently used in historical narratives. ${ }^{3}$

3. In Lytkin's terms, elbeszélő jövő in Hungarian and будущее повествовательHoe in Russian. 
Lytkin stresses that these tenses are, in fact, differentiated in the Komi dialects besides Udora. However, Cypanov (2005: 146) mentions that the use of the present tense in contexts where the future would be expected is common in the Komi dialects. To our knowledge, there is no study devoted only to the historical narrative tense in Komi standard varieties or in dialects, but the phenomenon itself has been recognised. Essentially, the system is constructed so that the present tense is used as a historical present and the future tense as a historical future, which Serebrennikov (1960: 51, 83) also points out. Other grammatical descriptions of the Komi languages (i.e. Lytkin 1955: 213-214; 1962: 251) also mention the use of the present and future to express historical meanings.

\section{Data}

In our study, we use a Udora dialect corpus we have compiled from various earlier resources and our own fieldwork. The size of the resulting corpus is 52,081 tokens, which are relatively evenly distributed over a period of one hundred years. For illustration, the Udora texts published by Uotila (1989) result in 8,00o tokens, and our contemporary fieldwork from the $2010 \mathrm{~s}$ is 17,975 tokens. Erik Vászolyi's published Udora texts total 13,558 tokens. All in all, there are 4,184 third-person verb forms that we have analysed, and they include 762 distinct verbs. Out of all the distinct verbs, 243 occur three times or more in the corpus. In most of the individual studies, we use three occurrences as a threshold for including a verb in the analysis. We determine that a verb belongs to one type or the other based on the most common third-person marker that occurs with the verb in the corpus. When we analysed the derivations, however, we also took rarer verbs into account. All verbs were initially extracted from the corpus using a morphological analyser for Komi (Rueter 200o) accessed using the Python package UralicNLP (Hämäläinen 2019), and then verified manually.

Several published text collections include samples from the Udora dialect. The earliest collected materials date back to the late 19th century and are published in Wichmann's 1916 work Syrjänische Volksdichtung, which contains three short texts from Udora. Another early source is Fokos-Fuchs' Zürjén szövegek from 1916, which contains a longer collection of narratives and other texts collected in 1913. Syrjänische Texte III (Uotila 1989) also includes a long section of Udora texts collected from a single speaker during the 1940s. There are no recordings for the earliest texts, but they are still 
very important and sizeable records of this dialect. Even if all individual examples cannot be confirmed with audio recordings, it seems plausible that the systematic patterns they contain are accurate and correct. Of the more contemporary materials, we have used the text collection Образцы комизырянской речи by Žilina and Sorvačeva (1971). These texts are primarily based on recordings made between the 1940s and 1960s, and have also been used in other studies on the Udora dialect, such as Ponarjadov (2004).

In the late 1950s, Erkki Itkonen took a two-week-long trip to Syktyvkar, where he recorded several Komi speakers (Itkonen 1958: 70) including people from the villages along the river Vaška. Günter Johannes Stipa also travelled to Syktyvkar with the goal of making recordings (Stipa 1962: 65-66), and his consultants included at least one Udora speaker from Koslan. Further work around Koslan followed soon, when Muusa Vahros-Pertamo went on a fieldwork trip to that area accompanied by the young Komi writer Albert Vaneev. There, they recorded a large collection of narratives, conversations and songs (Vahros-Pertamo 1963), which to our knowledge have not been published. Later in the 1960s, Erik Vászolyi also worked in the area, and his texts have been published (Vászolyi-Vasse 1999). Vászolyi’s work is particularly significant as it is one of the rare collections that includes recordings from the Upper Mezen river; most of the materials published from Udora have focused on Vaška and Lower Mezen.

As the audio collections of Itkonen, Stipa, Vahros-Pertamo and Vászolyi are archived in the Institute for the Languages of Finland, the majority of the audio recordings were available to us. These earlier materials are further supplemented with materials recorded by the authors in 2012 and 2013. These materials have been archived in the Language Bank of Finland and are available for research use (http://urn.fi/urn:nbn:fi:lb-2021111821). See also the online appendix for a complete listing of the examples used in this study.

There are also published sources that we have not used, especially folkloric materials that include segments in the Udora dialect and certain dictionaries that contain phrases in the dialect. Our main reason for leaving these sources out has been practical, as we feel that the current corpus is large enough for the current investigation. There are also methodological aspects, as we usually cannot know the process through which the folkloric texts were edited, whereas with linguistic transcriptions we should assume that exact linguistic representation has been the goal. At the same time, the dictionary examples may be too fragmentary to allow for fuller analysis. That said, dictionaries (i.e. Fokos-Fuchs 1959, Beznosikova et al. 
2012) could be very useful additional sources and have also been used in previous works on this topic, for example, by Lytkin (1969: 99). Ideally, these sources could be used to verify or refine our results.

Additionally, as there are still untranscribed recordings in both the earlier and contemporary materials, transcribing more recordings would be one way to obtain additional information, especially about the areal and temporal nuances of different questions related to the Udora dialect. We aim, however, to provide currently available results using the existing materials, as materials can always be increased and refined.

\section{Analysis}

\section{I. Distinct tense markers as two conjugation types in Udora}

Earlier research indicates that most verbs in the Udora dialect systematically select one of the two forms under investigation in the third person (Ponarjadov 2004). Earlier descriptions have led to the conclusion that the use of these allomorphs in the Udora dialect is primarily a lexical question, representing essentially two conjugation types, and possibly originating from Proto-Uralic stem vowels (Lytkin 1969: 97). Our study attempts to provide a synchronic description, so we do not make broader comparisons between the Uralic languages here. According to common morphological models, a conjugation is defined as a class of verbs, all of which take the same set of inflectional allomorphs (cf., e.g. Dixon 2010: 334). In the case of the Udora dialect, these conjugations differ only in the third person. Bakró-Nagy, Laakso and Skribnik (2020: 33) emphasise that the term conjugation is used in very different ways in different linguistic traditions. What we mean here by conjugation is strongly connected to the Uralic tradition, where it is used in Mari and Udmurt research to mark the two main verbal inflection types.

The phenomenon discussed here can be illustrated with (6):

(6) Иван Царевич мӧдасылас сувтас, а кар сулалӧ.

ivan tsarević med-asil-as suvt-as,

Ivan Tsarevich other-morning-3SG.INE get_up-FUT.3SG

a kar sulal-e.

but city stand-PRS.3SG

'Ivan Tsarevich gets up the next morning, and the city is [still] standing.' (Fokos-Fuchs 1916: 96) 
In this example, the event described takes place the next day, and Ivan Tsarevich getting up and the city still standing are presented as consequently occurring events. Of course, it can be surmised that some more complex temporal distinction is marked here. In Section 5.3, we discuss this further. The next example comes from the monograph describing the Udora dialect:

(7) Мунӧныс, мунӧныс, вартасны, вартасны дай тэсӧ и лягей.

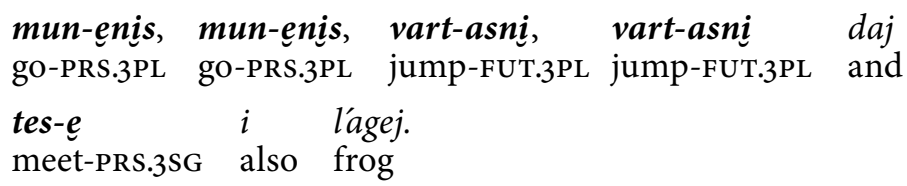

'They walk and walk, gallop and gallop onward, and meet a frog.' (Sorvačeva \& Beznosikova 1990: 68)

In the middle part of (7), the third-person marking switches from - $e$ - to -as-, and then back to - $e$ - again at the end. The durations of the activities described here may be different, as the general act of going can be understood as a longer process than that of jumping, but then the verb тэсны /tesni/ 'meet'4 that follows is again marked with - - -. In our corpus, all instances of this verb 'meet' occur with - $e_{-}^{-}$, as is overwhelmingly the case for the verb 'go', while 'jump' always occurs with -as-. This is not entirely without exception, but the system appears to be very regular. The same explanation also holds consistently for the verbs in (6). Table 2 lists the most frequently occurring verbs that appear with -e-, while Table 3 lists the most frequent verbs that take-as-. For a more thorough listing, please refer to the online appendix.

When looking at Tables 2 and 3 (on pp. 158-159), we can see that none of the very frequent verbs are particularly ambiguous when it comes to which form they use. It has been suggested in earlier literature that the verb шуны /šuni/ 'say' does not show a clear preference for one form over the other (Ponarjadov 2004: 108), but our data shows that with enough examples, a preference does emerge. All of the verbs in Table 2 are intransitive in Komi. We look into this phenomenon more closely in Section 5.2.

Verbs that are marked in the third person with -as- are significantly more numerous than verbs marked with $-e_{-}^{-}$. This is noteworthy, as this

4. This is an intransitive verb in Udora dialect, so the frog is the subject, and the other participant, if expressed, would be marked with the dative case. 
pattern already deviates very strongly from Standard Komi, where, as expected, the absolute number of present-marked verbs is higher than that of future-marked ones in a given corpus. The group of verbs that consistently occurs with - $e$ - is also significantly smaller than that of -as- verbs. Based on the data presented here, we can conclude that the analysis of the Udora system as lexically selected allomorphy holds relatively well. The exceptions are important, and will be analysed in detail, but the overall picture remains that the majority of occurrences of a given verb use either - $e$ - or -as- to mark the non-past tense. Next, we will try to analyse some of the properties of these conjugation groups.

\subsection{Correlation with transitivity}

As was discussed above, transitivity has traditionally been connected to the development of third-person verb marking in Komi. In the Old Komi materials presented by Lytkin, all of the verbs that occur with the contemporary present-tense marker seem to be intransitive, whereas those with the future marker include both transitives and intransitives (Lytkin 1952: 111-112; Bartens 2000: 118). According to Lytkin's analysis, Old Komi had undergone a development towards object conjugation, which subsequently ceased and developed into present and future markers (Lytkin 1977b: 6364). Lytkin also states that this development is somehow still visible in the Udora dialect (see Section 5.6 for further discussion).

Given this background, it is crucial to evaluate how the two verb endings under investigation are connected to transitivity. To do so, we have classified the Udora Komi verbs according to their transitivity. We used two categories for the classification: transitive and intransitive. These were primarily defined by the verbs' ability to take a direct object, based on corpus data, and by the presence of valency-increasing or valency-decreasing derivations in specific verbs. We include the classification in the online appendix to this paper. Next, we describe the results of this investigation. As previously mentioned in the description of our dataset, we used three occurrences as a threshold for which verbs to include. As shown in Section 5.1, relatively few verbs absolutely always occur in one of the types, but with enough examples, a clear pattern emerges. Table 4 shows the relation between the conjugation markers and the proportion of transitive and intransitive verbs that use them. 
Table 2: Most frequent verbs occurring with the conjugation - $e$ -

\begin{tabular}{|c|c|c|c|c|c|}
\hline Verb & Transitivity & Translation & $-a s-$ & $-e-$ & Total \\
\hline loni & IV & be; become & 14 & 160 & 174 \\
\hline munni & IV & go & 16 & 107 & 123 \\
\hline kovni & IV & have to & 1 & 112 & 113 \\
\hline lokni & IV & come & 11 & 59 & 70 \\
\hline petni & IV & exit & 5 & 48 & 53 \\
\hline ovlivlini & IV & happen (freq.) & $\mathrm{o}$ & 52 & 52 \\
\hline lebni & IV & fly, glide, rush & 1 & 39 & 40 \\
\hline ovni & IV & live & 1 & 36 & 37 \\
\hline śurni & IV & occur & 1 & 32 & 33 \\
\hline pišjinini & IV & flee & 5 & 27 & 32 \\
\hline kolni $i$ & IV & remain & 12 & 15 & 27 \\
\hline sulavni & IV & stand & $\mathrm{O}$ & 26 & 26 \\
\hline kivni & IV & hear & 7 & 18 & 25 \\
\hline vetlini & IV & go around & 1 & 22 & 23 \\
\hline pukavni & IV & sit & 1 & 21 & 22 \\
\hline uśni & IV & fall & 3 & 17 & 20 \\
\hline poźni & IV & can & 2 & 16 & 18 \\
\hline$u z ́ n i$ & IV & sleep & 5 & 11 & 16 \\
\hline kujlini & IV & be lying down & 1 & 13 & 14 \\
\hline kuvni & IV & die & 1 & 11 & 12 \\
\hline tesni & IV & meet & $\mathrm{O}$ & 12 & 12 \\
\hline vetledlini & IV & go around, walk around & 1 & 9 & 10 \\
\hline vivni & IV & $\begin{array}{l}\text { be (used in a compound } \\
\text { verb with ovni 'live') }\end{array}$ & 3 & 7 & 10 \\
\hline petavni & IV & exit (freq.) & 1 & 9 & 10 \\
\hline tidavni & IV & appear & $\mathrm{o}$ & 10 & 10 \\
\hline berdni & IV & cry & $\mathrm{O}$ & 9 & 9 \\
\hline kojni & IV & mate (of birds) & o & 9 & 9 \\
\hline vorsni & IV & play & $\mathrm{O}$ & 8 & 8 \\
\hline gorzini & IV & scream, yell & $\mathrm{o}$ & 8 & 8 \\
\hline kivlivilini & IV & listen & $\mathrm{o}$ & 8 & 8 \\
\hline tuni & IV & flood & 1 & 7 & 8 \\
\hline udzavni & IV & work & 1 & 7 & 8 \\
\hline dumajtćini & IV & ponder & 1 & 6 & 7 \\
\hline śorńitni & IV & speak & 1 & 6 & 7 \\
\hline šuśisśinini & IV & be called & o & 7 & 7 \\
\hline
\end{tabular}


Tense and aspect in Udora Komi

Table 3: Most frequent verbs occurring with the conjugation -as-

\begin{tabular}{|c|c|c|c|c|c|}
\hline Verb & Transitivity & Translation & $-a s-$ & $-e-$ & Total \\
\hline šuni & TV & say & 211 & 75 & 286 \\
\hline pondini & IV & start & 152 & $\mathrm{o}$ & 152 \\
\hline medni & IV & go (for) & 103 & 2 & 105 \\
\hline voni & IV & come, arrive & 96 & 3 & 99 \\
\hline bośtni & TV & take & 85 & 1 & 86 \\
\hline puktini & TV & put & 62 & 5 & 67 \\
\hline karni & $\mathrm{TV}$ & do & 43 & 8 & 51 \\
\hline pukśini & IV & sit (down) & 42 & 6 & 48 \\
\hline pirni & IV & enter & 44 & 2 & 46 \\
\hline kijni & TV & hunt & 28 & 11 & 39 \\
\hline suvtni & IV & stand up & 36 & $\mathrm{O}$ & 36 \\
\hline tećni & TV & gather & 30 & 1 & 31 \\
\hline većni & TV & make, do & 25 & 5 & 30 \\
\hline leźni & $\mathrm{TV}$ & let & 28 & 1 & 29 \\
\hline vajni & $\mathrm{TV}$ & bring or take (by carrying) & 27 & 1 & 28 \\
\hline viźédni & TV & look & 22 & 3 & 25 \\
\hline viśtavni & TV & $\begin{array}{l}\text { tell, express oneself; } \\
\text { give a speech }\end{array}$ & 14 & 11 & 25 \\
\hline śetni & $\mathrm{TV}$ & give & 20 & 5 & 25 \\
\hline aźźzini & TV & see & 24 & o & 24 \\
\hline kutni & TV & hold & 22 & 2 & 24 \\
\hline dumajtni & TV & think & 19 & 4 & 23 \\
\hline kiskini & TV & pull & 17 & 6 & 23 \\
\hline korni & $\mathrm{TV}$ & ask & 20 & 2 & 22 \\
\hline nuni & TV & bring or take (on foot) & 17 & 4 & 21 \\
\hline povźini & IV & get frightened & 19 & $\mathrm{o}$ & 19 \\
\hline śojni & TV & eat & 12 & 7 & 19 \\
\hline juavni & TV & ask & 15 & 4 & 19 \\
\hline vermini & $\mathrm{TV}$ & be able to & 18 & $\mathrm{o}$ & 18 \\
\hline leptini & TV & rise & 12 & 4 & 16 \\
\hline śijavni & $\mathrm{TV}$ & set a trap & 16 & o & 16 \\
\hline viźni & TV & keep & 12 & 3 & 15 \\
\hline lijni & TV & shoot & 14 & 1 & 15 \\
\hline juni & TV & drink & 14 & 1 & 15 \\
\hline domni & TV & bridle, rein & 14 & $\mathrm{O}$ & 14 \\
\hline kani & IV & climb up & 13 & 1 & 14 \\
\hline
\end{tabular}


Table 4: Transitivity and conjugations

\begin{tabular}{llc}
\hline Conjugation & Intransitive & Transitive \\
\hline$-a s-$ & 56 & 114 \\
$-e-$ & 63 & 6 \\
\hline
\end{tabular}

In our data, there are very few transitive verbs belonging to the - $e$ - conjugation, and none of them are frequent verbs, with all six examples belonging to the threshold category that has only three examples. Meanwhile, the - $e$-type contains both transitive and intransitive verbs in fairly equal proportion. We can confirm with Pearson's Chi-squared test that this distribution is statistically highly significant $(\mathrm{p}<0.001)$. Essentially, we are observing variation within the category of intransitive verbs, or, to put it more precisely, we can see that some intransitive verbs are marked distinctly from all other verbs. We can also state as one of our results that there are no frequent transitive verbs in the Udora dialect that would prefer the - e-conjugation.

One of the exceptions in the data is the verb повзьӧдльны /povźedlini/ 'frighten sb. repeatedly', which occurs three times and is always marked with the conjugation - $e$-. It is worth noting that this verb is also a frequentative. In the data, it occurs in a single text in which all verbs are similarly marked (Uotila 1989: text 206). In our classification, the verb бӧрдӧдны /berdedni/ 'cry a lament, lament sb./sth.' is another transitive verb that appears to fall into this group, but it also occurs only three times, two of which use the - $e$ - conjugation. These examples show that when we start to examine rarer verbs, it also becomes more difficult to establish which pattern they belong to. It is also noteworthy that both of these verbs are causatives derived with - ed-.

Similarly, the reflexive derivation корсисьны /korśiśni/ 'search for a long time' is classified here as transitive, as we do have an example where it has a direct object, although most of the time the object is not present, and such a derivation could be expected to be intransitive. These examples illustrate how our transitivity classification scheme could be further elaborated. With this in mind, a fruitful direction for future research would be to tag all objects separately in the corpus. For our current results and investigation, however, the scheme used now appears to be sufficient. Another thing these individual exceptions illustrate is that when there are only a handful of examples, all occurrences of a verb are often present in 
the same narrative, which may further influence the conjugation patterns, as we will discuss in Section 5.5.

Our analysis of the correlation between the conjugations and transitivity confirms the previous idea that the choice of morpheme is connected to transitivity, but with subtle differences, since transitivity alone does not explain the system we encounter in Udora. Instead, transitivity represents one clear boundary: the - $e$ - conjugation is not used with transitive verbs. This means that the factor determining which conjugation is selected must occur within the category of intransitive verbs. To provide a more comprehensive explanation of the factors at play here, we will next analyse questions of aspect and derivation.

\subsection{Aspect and temporal continuity}

As we can conclude from the previous analysis that all frequent transitive verbs belong to the -as- conjugation type, and that intransitive verbs can belong to either, we end up with two groups of intransitive verbs. We also find that the intransitive verbs in the Udora corpus are evenly split between the two patterns. The next question is which factors could be behind this alignment. As discussed in Section 2 on earlier research, it has been suggested that action verbs and verbs of movement would use the - e-conjugation. Lytkin (1961: 53-54) was not convinced that these were the actual factors behind the situation in contemporary Udora. Our suggestion is that the verbs that use the -e-conjugation appear to be temporally continuous. This contrasts with intransitive verbs marked with -as-, which can be analysed as being temporally bound. This definition is not perfect, but it does capture something in the difference between two groups of verbs. The lexical aspect of individual verbs would therefore appear to be one of the defining parameters. This distinction has previously been useful in categorising the use of other grammatical structures in Komi, for example in the study of augmentative verb forms by Todesk (2015), where the telicity of the event was shown to be central in determining the semantic reading of the comparative clitic - $\breve{z} i k$ when used with verbs. In the case of Udora, the situation is not so straightforward, as the categories presented in Section 5.1 do not fall as cleanly into aspectual groups. Indeed, 'die' and 'sleep' are the exact verbs Dahl (1985: 26) uses as examples of lexemes that have different aspectual potential: in our data, these are both firmly - $e$ conjugation verbs. 
It is still worth looking more closely into whether lexical aspect could be a suitable determining factor. Concerning temporal continuity, verbs such as 'climb', in the sense of 'reach the top of the mountain', have a necessary endpoint, whereas verbs such as 'move' have no inherent end (cf. Filip 2012: 727). Similarly, 'stand' is a continuous process, but 'stand up' is temporally bounded. An opposition of this type could also be postulated between the verbs воны /voni/ 'come, arrive' and локны /lokni/ 'come'. The concept of telicity in itself may not be sufficient to describe the Udora phenomenon, as classifying individual verbs without context into telic and atelic may not capture their different uses (Comrie 1976: 45). Dahl (1985: 26-27) has also argued that the 'inherent aspectual meaning' of a verb can be very difficult to define based on different possible uses. In a similar vein, Croft (2012) emphasises that predicates have the potential to be conceptualised as different aspectual types. The reason we have not yet started to distinguish these types more carefully at the contextual level is the lack of variation we see in the Udora data: as we showed in Section 5.1, each verb is relatively strongly drawn to one conjugation. We will go through some key exceptions separately below. If we can show that lexical aspect is a decisive factor behind the choice of verb form in Udora, this would also help to explain why some verbs, namely those which are more temporally bound, behave similarly to transitive verbs. Indeed, Hopper and Thompson (1980) have associated transitivity with both higher telicity and punctuality cross-linguistically. As discussed in Section 3.2, the morphologically marked future tense we find in Standard Komi has also been described as having aspectual connotations referring to single events that have endpoints. When we look at the verb groupings in Tables 2 and 3 , this explanation seems to hold some weight. Table 2 also shows several instances of derivations.

The majority of verbs that use the - $e$ - conjugation are verbs that describe an ongoing process without an obvious endpoint, such as 'stand', 'be', 'sit', and 'sleep'. That said, verbs such as тәсны /tesni/ 'meet (intr.)', кувны /kuvni/ 'die' and nетны /petni / 'exit' are bit at odds with this description and may call for a different analysis. There are also some relatively rare process verbs that use the -e - conjugation, such as 6 bıдмьны /bidmini/ 'grow (intr.)', кульмыныь /kul'mini/ 'spawn', сывны /sivni/ 'melt', чордны /ćordni/ 'harden' and myны /tuni/ 'rise (of water)'. The verbs nöдны /pedni / 'drown; suffocate', вӧйны /vejni/ 'sink, go underwater' and yсьны /uśni/ 'fall' can also be seen as belonging to this group. To explain these cases, some other parameter than telicity needs to be considered. One such 
parameter could be the lack of volition, as the examples above include processes that do not have a conscious subject. This is also clear in the case of the - $e$ - conjugation verb пеждыны /peždini / 'be released (of a trigger)'.

We can also suggest that among the rarer lexical items, verbs describing speech and vocalisations appear to occur commonly in the - e-conjugation. This is true for both human and animal vocalisations, with verbs such as серавны /śeravni/ 'laugh' and горзыны /gorzini/ 'scream, yell', but also баксыныь /baksini/ 'moo; bleat (of cows or sheep)', кӧкны /kekni/ 'cuckoo' and шкоргыны /škorgini / 'roar' belonging to this group. Example (8) illustrates this use.

(8) Кырсизь кӧ тювкӧтчӧ - зэра лоӧ.

kirśiź ke túukẹćć-e - zera lo-ę.

black_woodpecker if call-PRS.3SG - rainy be-PRS.3SG

'If a black woodpecker calls, it is going to rain.' (Žilina \& Sorvačeva 1971: 268)

The intransitive verbs marked with -as- form a few logical groups. One of these is momentaneous verbs, which occur in this form almost without exception. We will discuss these in more detail in Section 5.4. We also find a number of verbs that denote motion taking place along some defined dimension, such as кайны /kani / or / kajni/ 'climb' (northern and southern dialectal variants both occur), кывтны /kivtni/ 'slide down' and лэччыны /leććini/ 'go down'. Verbs of posture change also fall firmly into the -as- conjugation.

Determining how productive the system truly is requires further research, especially in the form of elicitation. There are numerous examples where one could think that, especially when an -as- verb shifts to the - $e$ conjugation, there is some kind of an extended temporal frame of reference. For instance, in (9), this is achieved using the frequentative derivation, which expresses that the otters regularly or repeatedly climb in a certain place.

(9) Вурд кыясны вӧралиссес берӧгӧ, вурд кытчы калывлӧ, лыаэс вылӧ.

vurd kij-asni veraliś-śes bereg-ę, vurd kićći

otter hunt-PRS.3PL hunter-PL beach-ILL otter where

ka-livl-e, lia-es vil-e.

climb-FREQ-PRS.3SG sand-PL top-ILL

'The hunters catch otters at the beach, where they tend to climb, on top of the sands.' (Uotila 1989: 362) 
The verb кыцйны / kijni / 'hunt' itself displays wide variation between conjugations, although it is predominantly an -as- conjugation verb. The variation we see here is not easy to explain, but we believe it is connected to the fact that verbs of hunting and fishing are used to mean both 'capture an animal using a certain method' and '(regularly) practice some specific capturing method'. Usually, however, the verb for practicing the action would be marked with a reflexive derivation: indeed, the verb кьйсьыны /kijśini/ 'go hunting', for instance, belongs exclusively to the - $e$ - conjugation.

At times, we can also see the difference at the contextual level; Example (10) shows this well.

(10) Буткыльтчылӧны, буткыльтчылӧны и некудз оз вермыны буткыльтны, и тшӧж пондас буткыльтны и буткыльтчас.

\begin{tabular}{|c|c|}
\hline $\begin{array}{l}i l^{\prime}-c^{\prime} c ́-\boldsymbol{i} l-\boldsymbol{e} n \boldsymbol{n} i, \\
\text { REFL-FREQ-PRS.3SG }\end{array}$ & $\begin{array}{l}\text { butkil'-ćć-il-eni } \\
\text { roll-REFL-FREQ-PRS.3SG }\end{array}$ \\
\hline
\end{tabular}

oz vermi-ni butkilti-ni, a čež pond-as NEG.PRS.3SG be_able-INF roll-CAUS-INF but duck start-FUT.3SG butkil'-t-ni $i \quad \boldsymbol{b u t k i l}^{\prime} \boldsymbol{c}^{c} \boldsymbol{c}$-as. push-CAUS-INF and roll-REFL-FUT.3SG

'They push and push, and cannot push (it) in any way, and then the duck starts to push, and it rolls (over).' (Fokos-Fuchs 1916: 157)

In this story, several characters are trying to get a stone to roll. They try many times to roll it, but to no avail (the action is marked with an underived transitive verb form in the infinitive). Then, the duck tries to roll the stone and manages to roll it over. The final attempt is temporally bounded, as it has a clear endpoint and there is a change in state. This is closely connected to the derivational operations we will analyse in the next section.

Another peculiar type of exception we can distinguish is where verbs marked with the - $e$ - conjugation express some sort of property or characteristic of their grammatical subject. This is connected to our earlier observation that the lack of volition appears to have some effect. If we look at (11), the transitive verb 'shoot' is used here not to describe the occurrence of a single shooting event, but rather a specific property of the gun, i.e. with the meaning 'the gun shoots well'.

(11) Писсяльыс вӧлӧма бур, лыйӧ бура.
piśśal'-is vęl-ęma
bur,
lij-e
bura.
gun-3SG be-PST2.3SG good shoot-PRS.3SG well
'The gun was good, it shoots well.' (Vászolyi-Vasse 1999: 502) 
In this case, the verb is used intransitively, and there is also a certain semantic ambiguity. However, describing the property of a gun is also temporally something very different from describing the action of shooting. Here we can present one more example where the temporal continuity is modified, as above, by the properties of the subject and the overall context, given the ambiguity of the verb. In (12), the verb 'hold' is used in the meaning of 'contain, be able to hold', with an inanimate subject 'trap'.'

(12) Капканыс кутӧ, овлывлӧ, комын тув и пуд.

\begin{tabular}{|c|c|c|}
\hline $\begin{array}{l}\text { kapkan-is } \\
\text { trap-3sG }\end{array}$ & $\begin{array}{l}\text { kut-e, } \\
\text { hold-PRS.3SG }\end{array}$ & $\begin{array}{l}o v \text { - } l i v-l-e, \\
\text { be-FREQ-FREQ-PRS.3SG }\end{array}$ \\
\hline $\begin{array}{ll}\text { tuv } & i \\
\text { pound } & \text { al }\end{array}$ & $\begin{array}{l}\text { pud. } \\
\text { pood }\end{array}$ & \\
\hline
\end{tabular}

'The trap can hold, ordinarily, thirty pounds and a pood.' (Uotila 1989: 354)

These kinds of instances suggest that the conjugations are used to express certain grammatical distinctions. It is important to note that all examples presented here show variation wherein a verb ordinarily occurring with -as-is used with - - - We saw in Section 5.1 that exceptions in the opposite direction also occur. In our materials, however, these exceptions are of a different type: they are related to narrative structure, which overrides the conjugation preferences set by the lexical aspect of individual verbs. We will discuss this in further detail in Section 5.5.

\subsection{Derivations and conjugation classes}

Komi has a complex system of verbal derivation. The most productive derivational categories are frequentative, reflexive, causative and momentaneous. These are able to combine with one another, which further enhances the complexity, and when it comes to frequentatives at least two types can be distinguished: -lij-and -al-. We illustrate the derivations here using the verbs гижны /gižni/ (in Udora also /gežni/) 'write' and мунны /munni/ 'go'.

We can see from Table 5 that not all intransitive verbs can be causativised. The meaning of the reflexive derivation also depends a great deal on

5. It has been pointed out to us that this sentence is, in fact, a bit odd, as thirty pounds is roughly equivalent to a pood. Perhaps the original intention of the speaker was to say that the trap 'holds thirty pounds, or, in other words, a pood'. 
the semantics of the stem verb: with intransitive verbs, the resulting verb can have a connotation of unintentional action; with verbs of posture, the meaning is usually a posture change; and when used with transitive verbs, the reflexive derivation renders them intransitive. Within the derivational system, the frequentative -li- is connected to the combining derivations - vli- and -livli-, as these all are used to mark action that is regular, repetitive or continuous (Fedjunëva et al. 2000: 297). The nuances of the system are more complicated, and Fedjunëva et al. (2000: 299) emphasise that there is also an allomorph -li- used to express an action that occurs only once. At the moment, we have not differentiated these meanings beyond stating that they are two frequentative categories. In combined derivations, we use the last morpheme to determine the category. In connection with the Udora conjugations and derivations, Serebrennikov (1963: 255) and Sorvačeva (1952: 46) have suggested that reflexive derivations would always belong to the - $e$ - conjugation.

Table 5: Komi verbal derivation system illustrated using a transitive and an intransitive verb.

\begin{tabular}{|c|c|c|c|c|}
\hline Derivation & Form & Meaning & Form & Meaning \\
\hline underived & gižni & write (trans.) & munni & go \\
\hline reflexive & gižśśni & sign up (intrans.) & munśini & go (unintentionally) \\
\hline causative & gižędni & $\begin{array}{l}\text { ask someone to } \\
\text { write (trans.) }\end{array}$ & - & - \\
\hline $\begin{array}{l}\text { frequen- } \\
\text { tative }\end{array}$ & gižavni & $\begin{array}{l}\text { write often } \\
\text { (trans.) }\end{array}$ & munavni & go (often) \\
\hline $\begin{array}{l}\text { frequen- } \\
\text { tative }\end{array}$ & gižlini & $\begin{array}{l}\text { write sometimes } \\
\text { (trans.) }\end{array}$ & munlini & go (sometimes) \\
\hline
\end{tabular}

Here, we have decided to test the correlation between the derivations first by verb type and then with regard to all verbs occurring in the corpus, without using the threshold of three occurrences. Table 6 shows how the derivations are distributed across the verbs that occur more than three times. 
Table 6: Derivations and verb types

\begin{tabular}{lrr}
\hline Derivation & $-a s-$ & $-e-$ \\
\hline causative & 26 & 2 \\
frequentative $-l i-$ & 8 & 5 \\
frequentative $-a l-$ & 17 & 12 \\
momentaneous & 2 & 0 \\
reflexive & 22 & 10 \\
underived & 95 & 40 \\
\hline
\end{tabular}

Table 7: Derivations and verb occurrences

\begin{tabular}{lrr}
\hline Derivation & $-a s-$ & $-\underline{e}-$ \\
\hline causative & 285 & 31 \\
frequentative -li- & 96 & 108 \\
frequentative -al- & 192 & 159 \\
momentaneous & 32 & 2 \\
reflexive & 265 & 114 \\
underived & 1785 & 1115 \\
\hline
\end{tabular}

In the Udora data, there are a number of situations where derivations change the conjugation type of the verb. We can describe a system in which the derivations are closely and often predictably linked to conjugation types. This supports the analysis according to which the conjugations would mark lexical aspect, which would then be independent for each derivation.

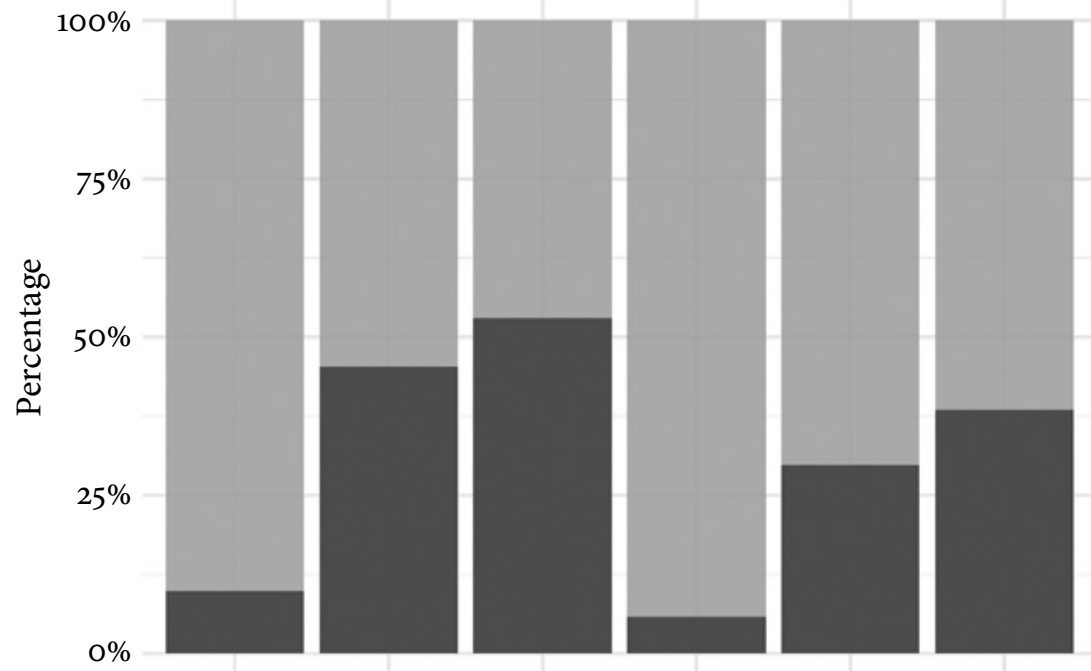

causative freq.-al- freq. -li- moment. reflexive underived Derivation type

Conjugation $\square-$-as-

Figure 2: Relationship between derivations and conjugations used, based on data in Table 7 
For example, there is an intransitive derivation of the transitive verb кутны /kutni/ 'hold; start', which is кутасьны /kutaśni/ 'try to catch' (used, for example, in children's games of tag or to describe when a child is learning to grasp items). The texts where this verb is used clearly describe the process of attempting to catch someone or something. Similarly, the derivation кутчысьны /kućiśni / 'catch from somewhere', also intransitive, shifts the verb into the -as-conjugation type. The difference here appears to be connected to the changed telicity of the derived verb. At this point, we also wish to draw attention to (12), where the transitive verb кутны /kutni / 'hold; start' was used with the - $e$ - conjugation under very specific circumstances.

Furthermore, we see that frequentative derivations do not change intransitives that occur with - $e$ - into the -as-conjugation. The derivations овны /ovni/ 'live' $\rightarrow$ овлывлыны /ovlivlini/ 'happen'; пышйыны /pišjini / 'escape' $\rightarrow$ nышъявны /pišjavni / 'be on the run'; nетны /petni/ 'exit' $\rightarrow$ nетавны /petavni/ 'be going out' all remain in the same conjugation as the verbs from which they are derived. This is also true of verbs such as ветлыны /vetlini/ 'go' $\rightarrow$ ветлӧдльны /vetledlini/ 'go', and $\rightarrow$ ветлывлыны /vetlivlini / 'go around'. We argue that the main reason for this is that when combined with verbs that are already temporally continuous, frequentative derivations serve only to expand the duration of the event, they do not change the verb's lexical aspect.

Predictably, the opposite shift from one conjugation type to the other does occur when a new frequentative verb is derived, and the -as- conjugation becomes more common. This kind of use is illustrated in (13).

(13) Урыс чувалігӧныс кывт кузяыс ёна вартлӧ.

$\begin{array}{llll}\text { ur-is } & \text { ćuval-igen-is } & k i v t & k u z ́ a-i s \\ \text { squirrel-3sG } & \text { be_in_heat-CVB.SIM-3SG } & \text { trapline } & \text { along-3SG } \\ \text { jona vart-l-e. } & & \\ \text { much jump-FREQ-PRS.3SG } & & \end{array}$

'When the squirrel is in heat, it often runs along the trapline' (Uotila 1989: 356)

Again, we see a change in conjugation type when the action becomes temporally more continuous. Similarly, the verb $\partial y z \partial ы н ы$ /dugdini/ 'stop' primarily occurs in the -as- conjugation. However, when it occurs in a frequentative derivation, we occasionally see a similar change, as in (14): 
(14) И тятейыс бӧрдӧмись дугдывлӧ.

$i$ t'atej-is berdegm-iś dugd-ivvl-e.

and baby-3SG crying-ELA stop-FREQ-PRS.3SG

'And the baby stops crying.' (Uotila 1989: 396)

This is not always a clear-cut process, and we can see that there is wide variation in the conjugations used with verbs formed with frequentative derivations. This variation is also evident from Figure 2.

In some instances, reflexive derivations can change a verb from one type to the other in either direction. When a reflexive derivation is used to detransitivise the verb, the pattern also tends to change. This can be expected, as the derivation changes the transitive verb into a temporally longer-lasting intransitive verb. All of the following transitive verbs switch to using the - e-conjugation in intransitive derivations: nyны /puni / 'boil' $\rightarrow$ пусивны /puśivni/ 'be boiling', кыйны /kijni/ 'fish or hunt (for something)' $\rightarrow$ кьйсьыı 'say' $\rightarrow$ uycьыıы /šuśini/ 'be called'. We can illustrate this with (15) and (16). In (15), we see the normal use of the transitive verb 'hunt'.

(15) К Кӧч кыясны капканӧн и лэчӧн.

kęć kij-asni kapkan-ęn $i$ leć-ęn.

hare hunt-FUT.3PL trap-INS and snare-INS

'The rabbit is hunted with traps and snares.' (Uotila 1989: 356)

When a corresponding intransitive verb is derived from this stem, as we see in (16), the conjugation type changes to - - -

(16) Лэчӧн кыйсьӧны; сияласны лэчсӧ кӧч кывт вылас.
leć-ęn
kij-ś-ên $\boldsymbol{i}$;
śijal-asni leć-sé
kéć
snare-INS
hunt-
kivt vil-as.
track on-3SG.ILL
'This is how one hunts with a snare; the snare is placed on the rabbit's track.' (Uotila 1989: 356)

However, we often see the opposite change when the same derivation is applied to an intransitive verb. The reason for this is connected to various distinct functions of Komi reflexive derivations, as discussed above. The change from - $e$ - to -as- takes place with derived verbs such as пукавны 
/pukavni/ 'sit' $\rightarrow$ nуксьььны /pukśini / 'sit down'; on the other hand, there is also a causative derivation of the same verb, $\rightarrow$ пуктыны /puktini/ 'put', which occurs with the -as-conjugation, as would be expected of a transitive verb.

A similar conjugation shift with reflexive derivations can also take place in the other direction. In (17), we see a typical use of the verb пукавны /pukavni/ 'sit'.

(17) А Баба-Ягаыс пукалӧ море дорын [...]

$\begin{array}{lllll}a & \text { baba jaga-is } & \text { puk-al-e } & \text { more dor-in } \\ \text { and Baba Yaga-3SG } & \text { sit-FREQ-PRS.3SG sea at-INE } \\ \text { 'And Baba Yaga is sitting by the sea [...]' (Fokos-Fuchs 1916: 160) }\end{array}$

The outcome of the derivation with an intransitive verb is different, and the resulting meaning is 'sit down', a temporally bounded action.

(18) А юр вылас тшӧж пуксяс.

a jur vil-as če ž puk-ś-as.

and head on-3SG.ILL duck sit-REFL-FUt.3SG

'And a duck sits down on the top of his head.' (Fokos-Fuchs 1916: 159)

In this light, it seems to us that the idea proposed earlier, that reflexive derivations would always occur with the -e - conjugation, is only part of the picture, and that the different outcomes of this derivation need to be examined based on the lexical aspect of the resulting verb and the multiple functions of reflexive derivations in Komi.

As noted by Ponarjadov (2004), momentaneous verbs regularly occur with the -as-conjugation. If we look simply at the percentages for which different derivations fall into the two conjugation types, as seen in Figure 2, we can observe that causatives and momentaneous verbs are the ones that most clearly avoid the - $e$ - conjugation. Other conjugation types occur with other derivations in similar proportions, even though in the corpus we see some processes that are related to both frequentatives and reflexives as well.

However, there appear to be subtle differences between the behaviour of momentaneous and causative derivations. Example (19) shows a momentaneous verb derived from the verb 'pour', which is itself a transitive -as- verb. 
(19) Мужик бӧра кисьтыштас и аслыс этша кольӧ.

\begin{tabular}{|c|c|c|c|}
\hline mužik bera & $k i s ́-t-i s ̌ t-a s$ & & aslis \\
\hline man again & pour-CAUS-MOM-FUT.3SG & and & 3SG.REFL.DAT \\
\hline
\end{tabular}

'The man pours again and leaves just a bit (of drink) for himself.' (Fokos-Fuchs 1916: 167)

When - $e$ - conjugation verbs are derived further with this same derivation, their conjugation type does not change, as we can see in (20).

(20) ̈два кодзувъясянь кельыд югыдтор усьыштӧ.

edva koźuv-jas-śań kel'idd jugid-tor uś-išst-e.

hardly star-PL-EGR pale light-thing fall-MOM-PRS.3SG

'Just a pale light falls from the stars.' (SKNA 291:1a)

Creating a momentaneous derivation therefore does not change the conjugation type of the base verb, but these hardly ever appear to be formed from verbs that typically occur with the - e-conjugation. One reason for this could be that these verbs are perceived as having a continuous temporal reading, which is not compatible with the punctual semantics of momentaneous derivations. In Standard Komi, however, they do occur regularly with momentaneous verbs, which points to a difference between the written language and the Udora dialect.

The fact that causative verbs typically belong to the conjugation type that is connected to transitive verbs is logical, as causative derivations are normally transitive (Dixon 2010: 169). Therefore we would not expect to find many such verbs with - $e$ -

It has also been reported that Udora reflexive derivations carry an inchoative meaning. The examples provided in Žilina and Sorvačeva (1971: 234) include локсьыны /lokśini/ 'start to go', петчыны /peććini/ 'start to exit' and сёйсьыныbl/śojśini/ 'start to eat; eat'. Nekrasova (2000: 48) also describes these Udora forms as reflexives, pointing to the examples мунсьыны /munśini / 'go' and гижсьььны /gižšini / 'write' (see the meaning in Standard Komi in Table 5). In these descriptions, the verbs are said to occur with - $e_{-}^{-}$, but as such forms are extremely rare or missing in our corpus, this interesting phenomenon must await further investigation. Lytkin (1961: 57) has also suggested that some onomatopoetic verbs in Udora would use the - $e$ - conjugation. Unfortunately we cannot verify this using 
the current data, although the fact that verbs of vocalisation employ this conjugation could possibly support this.

\subsection{The narrative use of tense markers in the Udora dialect}

In the Udora dialect, as previously discussed, the Standard Komi present and future markers appear to be a primarily lexical feature that is connected to lexical aspect. However, as very few verbs fall absolutely into one conjugation or the other, we have decided to examine the broader context of their occurrence at the textual level. The narrative use of the Komi future tense has been regularly mentioned in the literature, as described in Section 3.2, and we can also find specific narrative-related phenomena in the Udora data.

The Udora data contains numerous instances where a narrative that has been in the past tense suddenly switches to using forms in -as-for all verbs. This can be compared, for instance, to the use of the past and historical present tenses in English. There, the variation in tenses can be connected to opening the narrative, with the tense returning to present in the coda section, among other structural functions (Schiffrin 1981, see also Fludernik 1991). A similar usage has also been described in Russian and other Slavic languages (Comrie 1976: 75-76). To our knowledge, tense variation in Komi narratives has not been studied extensively, although it is known that both present and future can also be used in narratives that describe past events, as was discussed in Section 3.2. In the Udora texts, we often encounter the use of verbs with -as-in parts of the story describing actively occurring events, whereas background information in the story appears either in the present tense, with the verbs either in the -as- or - $e$ - conjugation, or in one of the past tenses. The system seems to be used in such a way that in the beginning, the tense becomes established, and the verbs marked with -as-indicate that the narrative is continuing in the same tense.

We can first discuss a series of examples from a complete published and recorded text. In the beginning, the fact that the story takes place in the past, and was not witnessed personally by the narrator, is marked with the second past tense in the verb 'be'. Otherwise, the tense use in the beginning of the story is according to the standard Udora system, i.e. the choice of form is lexical and does not indicate a tense difference between the verbs. As the first sentence of the story already situates it in the past tense, we must consider the whole following section to already represent some type of historical present tense: 
(21) Вот тар кыйӧм эшшӧ вӧлӧма сэтшӧм жӧ случай. Ӧти вӧралісь мунӧ вӧрӧ, ружйӧ сьӧрсис. Видзӧдас: пу вылын пукалӧныс таръяс. Видзӧдас да лыддяс: сё кымын унджык гашкӧ вӧлӧма сэні. И думайтӧ: [...]

$\begin{array}{llllll}\text { vot } & \text { tar } & \text { kij-ęm } & \text { ešše } & \text { vel-ęma } & \text { sečęm } \\ \text { well } & \text { grouse } & \text { hunt-PST.PTCP also } & \text { be-PST2.3SG } & \text { this_kind } \\ \check{z} e & \text { slućaj. } & \text { et'i veraliś } & \text { mun-e } & \text { vere. } & \text { ružje } \\ \text { FOC } & \text { event } & \text { one hunter } & \text { go-PRS.3SG } & \text { forest-ILL } & \text { rifle }\end{array}$

śérś-is. viźed-as: pu vil-in pukal-ęnis hold-PST.3SG look-FUT.3Sg tree top-INE sit-PRS.3PL

tar-jas. viźed-as da lid'd'as: śo kimin grouse-PL look-FUT.3Sg and count-FUT.3Sg hundred about un-žik gaške velegma seni. $i$ dumajt-e : lot-CMP maybe be-PST2.3SG there and think-FUT.3SG

'Well there was also a story about grouse hunting. One hunter goes to the forest, with a rifle. He sees: the grouses are sitting in a tree. He takes a look and counts: around a hundred, maybe more [grouses] there were. And he thinks: [...]' (Vászolyi-Vasse 1999: 440)

This continues into the second part of the narrative, presented in (22), where the protagonist ponders where to shoot:

(22) Кытчӧ-я лыя? Улӧ, вылӧ или шӧрас? Кысь унджык сюрӧ? Думайтас да и: лыйла, медджӧ, вылӧ!

kiććce-ja lij-a? ul-ẹ, vil-e il'i šęr-as?

where-Q shoot-PRS.1SG under-ILL top-ILL or middle-3SG.ILL kiśs un-žik śur-e? dumajt-as da $i$ : where.ELA lot-CMP catch-PRS.3Sg think-FUT.3Sg and and lij-l-a, mežžes, vill-ę! shoot-FREQ-PRS.1SG FOC top-ILL

'Where should I shoot? Below, above or in the middle? How do I catch the most? He decides: I'll shoot, you see, from above!' (Vászolyi-Vasse 1999: 440)

After this, however, comes the climax of the story. This is a sequence of events, where the first grouse falls onto the one under it and so on, causing a chain reaction of collapsing grouses. Every verb in this sequence is marked with the -as-conjugation. This can be compared to the description of the Standard Komi future tense use in Section 3.2, where the future 
tense was described in point five as being used to bring the speaker closer to the events and to make the speech more vivid. Similar use connected to plot progression, or tellability, has also been described for the historical present tense in English (Fludernik 1991: 392-393). It could also be argued that (21) and (22) both contain background information, while (23) is distinctly marked. Distinguishing between narrative events has been suggested as one use of the historical present, and it has also been proposed that individual tenses have a tendency to cluster together for functional and discourse-level reasons (Schiffrin 1981: 52). The next segment is also similar to complicating action clauses, which Schiffrin (1981: 48) describes as being used to relay a series of temporally ordered narrative events.

(23) Муй нӧ, лыяс: вылыс тарыд усяс. Уськӧдас мӧдсӧ, мӧдыс коймӧдсӧ, нёльӧдыс витӧдсӧ, дасӧдсӧ, ветымынӧдсӧ и сёӧдсӧ, ставыс уськӧдас. Мунас пу дорад, вӧвтӧ матӧдас сэтчӧ. Сӧвтас дойд тыр. Да коляс на мӧд сымыттӧм сэтчӧ. Сідз и сэтчӧ прӧпадитас ставыс.

muj ne, lij-as: vil-as tar-id uś-as. what FOC shoot-FUT.3SG above-3SG grouse-2SG fall-FUT.3SG uś-ked-as med-se. med-is kojmed-se. fall-CAUS-FUT.3SG second-ACC second-3sg third-ACC noléd-is vited-se, dased-se, vetimined-se $i$ fourth-3sG fifth-ACC tenth-ACC fiftieth-ACC and śoed-se, stav-is uś-kéd-as. mun-as hundreth-ACC everything-3Sg fall-CAUS-FUT.3SG go-FUT.3SG pu dor-ad vev-te mated-as sećce tree at-2SG.ILL horse-2SG.ACC bring_near-FUT.3SG there sev-t-as dojd tir. da kol'as na put-CAUS-FUT.3Sg sledge full and remain-FUt.3sg still med simittem sećće. siź $i$ sećće other so_much there so and there

prepadit-as stav-is.

get_lost-FUT.3SG everything-3SG

'Well, he shoots: the uppermost grouse falls. It falls onto the second one, the second onto the third, the fourth onto the fifth, tenth, fiftieth and the hundredth, they all fall. He goes to the tree, brings the horse closer. Piles his sledge full. And he still leaves so much there. And so all that got wasted.' (Vászolyi-Vasse 1999: 440) 
The story ends with the laughter of the interviewer, Albert Vaneev, who is also a native Udora dialect speaker.

(24) Vaneev: Ӧні на сисьмӧ. Ekimov: Ӧні на сисьмӧ, да.

enni na śiśm-e. enni na śiśm-e, da. now still rot-PRS.3SG now still rot-PRS.3SG yes

'Vaneev: Still they rot. Ekimov: Still they rot, right.' (Vászolyi-Vasse 1999: 440; edited after the recording SKNA 13761: 2az)

At this point the story is already over, and we return to the expected Udora system, with the next verb marked with the - $e$-conjugation. This is the verb сисьмыны /śiśmini / 'rot', an example of a non-volitional process verb, which we earlier analysed as often belonging to this conjugation. Most importantly, this narrative shows several instances where verbs that typically belong to the - $e$ - conjugation occur with -as-. For example, this happens to the verbs мунны /munni/ 'go', кольны /kol'ni/ 'remain' and усьны /uśni/ 'fall'. We can therefore show that in some narrative contexts, the default third-person marking for different verbs can be overridden.

This temporal shift is not obligatory, as the narrator always has various means available to express events in the past. There are also texts where every verb is marked with - $\underline{-}$ - in the third person. We can illustrate this here with an example from Syrjänische Texte III.

(25) Сірп, сія овлывлӧ вурӧма пом помӧ дӧра. Пасьтаыс дӧраыслӧн кык аршын. Сія овлывлӧ дас аршын кузя. Вӧдзӧ вийым сірп шӧрас мешӧк, шуӧны сірп сітанӧн. Вӧдзӧ вийым сірп вылас вурлӧма пуись карӧм табъес. Улысла-дорас вурлӧма из ротӧ. Вӧдзӧ вийым мӧд мӧдӧр сірп помас гез, метра куим кузя. Гессӧ вурӧма сірп помас улысладорас и вылысладорас. Сы гезйӧн ваӧдіс кыскӧны. Улысладор гессӧ гаровтӧны кокӧ а вылысладор гезнас кыскӧны кийӧн. Сірпӧны куим морт, кык морт кыскӧ ва кузяыс а коймӧд черисӧ сірпланьыс повзьӧдӧ бедйӧн.

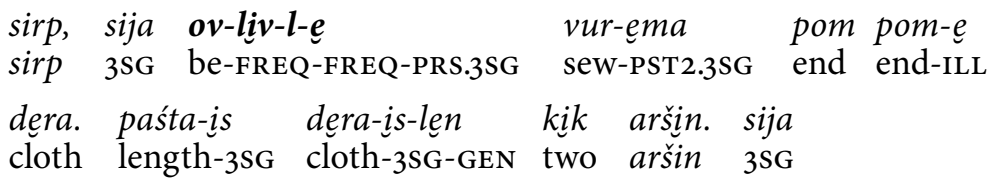

$\begin{array}{llllll}\text { ov-liv-l-e } & \text { das } & \text { aršin kuźa. vé́e vijim sirp } \\ \text { be-FREQ-FREQ-PRS.3SG } & \text { ten aršin long then } & \text { EX sirp }\end{array}$




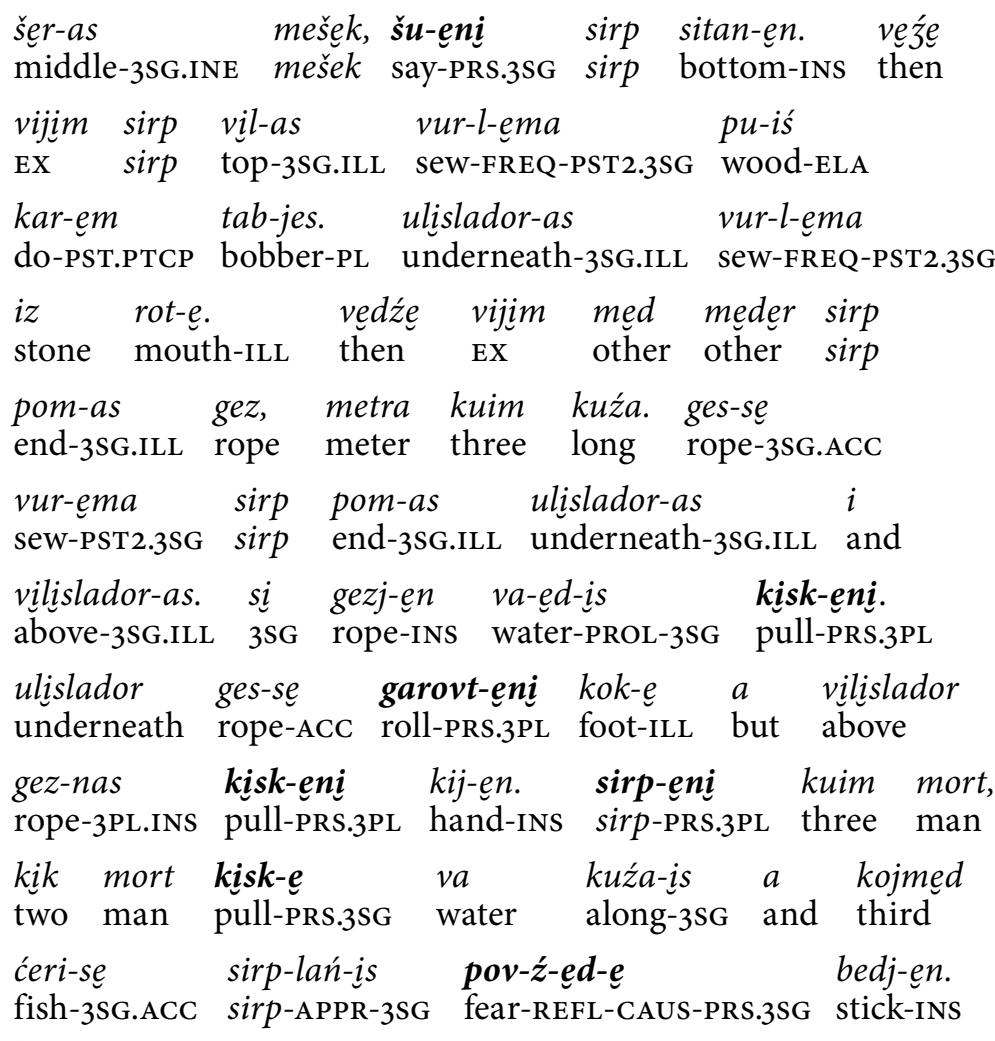

'A sirp, it may be (made so) that a cloth is sewn from one end to another. It is two aršins long. It can be ten metres long. Then in the middle of the sirp there is mešek, it is called the sirp bottom. Then, to the top of the sirp, are sewn wooden bobbers. To the underside a stone is sewn, to the mouth. Then, at the other end, there is a rope, it is three metres long. The rope is sewn to the end of the sirp from underneath and from above. With this rope, it is pulled along the water. The lower rope is rolled by foot, and the upper rope is pulled by hand. Three persons use the sirp, two pull it along the water and the third frightens the fish toward the sirp with a stick.' (Uotila 1989: 340)

There are, however, crucial differences between this text and the previous example. In (23), the events described serve a very specific function in advancing the narrative plot, and they have a clear temporal order. The protagonist shoots and causes the birds to fall, then he gets his horse and sledge, then packs the birds up in one sequence of actions. Example (25), by 
contrast, is a more static description of a type of fishing equipment. In the very first phrase, we have the verb form /ovlivle/, which is a frequentative derivation of 'be'. There are also numerous verbs in the second past tense formed with frequentative derivations. It is also noteworthy that, although the example includes numerous transitive verbs, they are used primarily without explicit objects. In the very end, we have an instance of a transitive verb with a direct object, in the phrase /ćerise povźeded / frightens the fish'. Still, the conjugation type does not change with each verb, but rather spans the entire text. This can be compared to the way the use of the Standard Komi present tense is described in Section 3.2, where the tense is described as also being used to mark events in the distant past, along with events that exist at all times. In this context, the narrator might have though of fishing with a sirp as an older practice, remote from the current situation (as the narrator was a prisoner of war in Finland when the narrative was being told), or as a general way of doing this activity that essentially exists at all times.

According to Cypanov (2005: 150), the historical future tense is used to some extent in Komi, but it is particularly common in Permian Komi, which has a stronger Russian influence. He points to parallels in Russian dialects where the historical future is used. As Udora is one of the Komi dialects with a relatively strong Russian influence, it does not seem impossible that Udora Komi speakers would have become accustomed to Russian narrative practices. As both different tense markers are used in Udora in these kinds of narrative functions, it is not clear whether we should assume contact influence or an independent development in the dialect. That said, this process in Udora clearly illustrates that there are at least some functions where the conjugations are not used to mark only verb-specific lexical aspect, and that they can acquire tense-like use in longer spans of text under certain conditions.

In Section 3.2, we mentioned that the Komi present tense is used to express events that are true at all times, as well as to mark distant events in folklore. This may offer a fruitful point of comparison between the contemporary Komi and Udora systems. In (21), we also see an instance where the second past tense is used to establish the timeframe of the narrative, after which the present and future tenses are used. A similar use has also been described in Standard Komi. In the next section, we provide a more detailed comparison between Old Komi and Udora, also with a view to contemporary Standard Komi. 


\subsection{Comparison to Old Komi}

The Old Komi corpus is extremely small, consisting of short texts on icons and historical manuscripts in the Old Komi script. This language form is attested from the 14th century, and it represents an extinct Komi dialect that was closely related to Udora and the Lower Vyčegda dialects. All in all, these materials consist of 233 words of connected text written in the Old Komi alphabet (Sidorov 1962: 189). In addition to these fragments, there is essentially one longer text in the Cyrillic alphabet that is thought to represent the same Old Komi language form, possibly having been copied from Old Komi originals. There are three known copies of this text. Two were used by Lytkin in his description of Old Komi: Lepehin's text and the Evgenian text. One more version was found and published by Sidorov (1962). With all of these texts taken together, but counting the text that exists in three versions only once, the entire Old Komi corpus is just under one thousand words.

These materials are now becoming more accessible than ever, as the characters used are currently in the Unicode standard under the Old Permic character block. The authors of this study have collected various versions of Old Komi texts published by Lytkin (1952) and Sidorov (1962), and constructed a corpus that is available online (Partanen 2021). We have analysed this corpus for various features, including instances of parallel forms existing in both Udora and Old Komi in other aspects of the lexicon and morphology, but crucially for the question at hand, we have morphologically annotated all third-person verbs in the present and future tense. We examined the corpus, which, to our knowledge, now contains all known Old Komi texts, and manually extracted all verbs that occur in the third person in the present or future. Table 8 provides a comparison of these verbs in Old Komi and our Udora materials.

The systems are very similar in the majority of cases, with Old Komi and Udora verbs employing the corresponding morphemes most of the time. We do see some differences, and the total number of verbs in the Old Komi corpus is very small, but the correspondences are still interesting and the pattern is so strong that it appears to be more than coincidental. Since the number of examples in the Old Komi corpus was so small, no further statistical tests were carried out. Most of the verbs occur only once in the Old Komi texts, and some are also absent from our Udora materials. There is also an example of the verb лолзьыны /lolźini/ 
Table 8: Old Komi and Udora third-person verbs compared

\begin{tabular}{|c|c|c|c|c|c|c|c|}
\hline Verb & UPA & $\begin{array}{l}\text { Trans- } \\
\text { lation }\end{array}$ & $\begin{array}{l}\text { Old } \\
\text { Komi }\end{array}$ & $\begin{array}{l}\text { Udo- } \\
\text { ra }\end{array}$ & $-e-$ & $-a s-$ & Comment \\
\hline вайны & vajni & bring & $-a s^{-}$ & $-a s^{-}$ & 1 & 27 & \\
\hline вайсьыны & vajśini & $\begin{array}{l}\text { bring } \\
\text { (refl.) }\end{array}$ & $-a s^{-}$ & - & $\mathrm{o}$ & $\mathrm{o}$ & $\begin{array}{l}\text { not found in } \\
\text { the corpus }\end{array}$ \\
\hline воны & voni & arrive & $-a s-$ & $-a s-$ & 3 & 96 & \\
\hline вуджны & $v u \check{n} n i$ & cross & $-a s_{-}$ & $-a s_{-}^{-}$ & $\mathrm{O}$ & 2 & \\
\hline кутны & kutni & hold & $-a s^{-}$ & $-a s^{-}$ & 2 & 22 & \\
\hline кывны & kivni & hear & $-a s-$ & $-e-$ & 18 & 7 & see Section 5.1 \\
\hline локны & lokni & come & $-e-$ & $-e-$ & 59 & 11 & \\
\hline лолзьыны & lolźini & revive & $-e-$ & $-a s^{-}$ & $\mathrm{o}$ & 2 & $\begin{array}{l}\text { semantic } \\
\text { difference }\end{array}$ \\
\hline лыддьыны & lid'd'ini & read & -ani- & $-a s^{-}$ & 1 & 6 & $\begin{array}{l}\text { cf. Upper } \\
\text { Sysola future }\end{array}$ \\
\hline лэдзны & leźni & let & $-a s-$ & $-a s-$ & 1 & 28 & \\
\hline петны & petni & exit & $-e-$ & $-e-$ & 48 & 5 & \\
\hline сетны & śetni & give & $-a s^{-}$ & $-a s^{-}$ & 5 & 20 & \\
\hline сулавны & sulavni & stand & $-e \underline{-}$ & $-e-$ & 26 & $\mathrm{o}$ & \\
\hline
\end{tabular}

(Old Komi) ловзььны /lovźini/ (Udora), where the meaning in Old Komi is 'be resurrected, born again', and which in our Udora examples is used to refer to dough rising. Earlier in our analysis, we stated that many of the process verbs like this would normally use the $-e$-conjugation in Udora. Additionally, Old Komi shows examples of morphemes that are similar to the future forms encountered in Upper Sysola, formed in the plural with /-anis/ (Žilina 1975: 118), which is another type of variation not present in Udora. As we have already analysed in the earlier sections, the system in Udora is not always clear-cut. There is variation, and some of it is strongly related to narrative structures that override the lexical aspect, which is the main factor behind the selection of allomorphs. A wider comparison would be necessary but it is not currently possible, at least with the Old Komi materials themselves.

As the Old Komi texts are of a religious nature, there are also newer editions of the same sentences. We will therefore take a brief look at the corresponding texts in contemporary Komi. If we look at the Old Komi 
text in (26), we see a short fragment that is also present in the contemporary Bible. One modern translation of the corresponding lines is: [...] but has crossed over from death to life. Very truly I tell you, a time is coming and has now come when the dead will hear the voice of the Son of God and those who hear will live. (The Holy Bible 2011: John 5:24-25). One modern Russian translation, on the other hand, is as follows: [...] но перешел от смерти в жизнь. Истинно, истинно говорю вам: наступает время, и настало уже, когда мертвые услышат глас Сына Божия и, усльшав, оживуm. (Biblija 2010: 1475). This text has an interesting tense structure with a clear future reference, which makes it relevant for further examination. In (26) from Old Komi, each third-person verb occurs in a different form, essentially following the conjugation pattern we see in Udora today. The transitive verb 'hear' occurs with -as-, as does the temporally bounded intransitive verb 'cross'. In contrast to these, the intransitive verbs 'come' and 'be born again' occur with -e - conjugation.

(26) [...] чӧчкӧ вузас куламлыс' олӧм пычкӧ, ина вэс'тас вӧйпам тийанлы, вэвэс' локтӧ йэз и ӧнэ вим куз'кӧ кулӧмайас кыласныс горасӧ йэн пилӧн, сэс' кылмыс' и лоิлз'ӧныс.

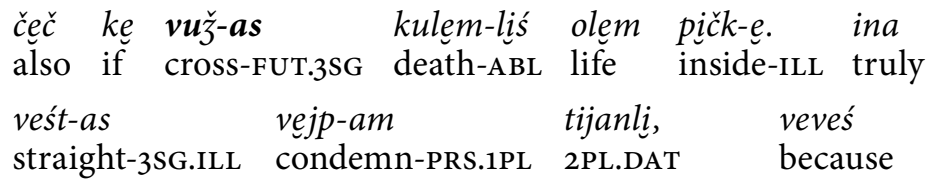

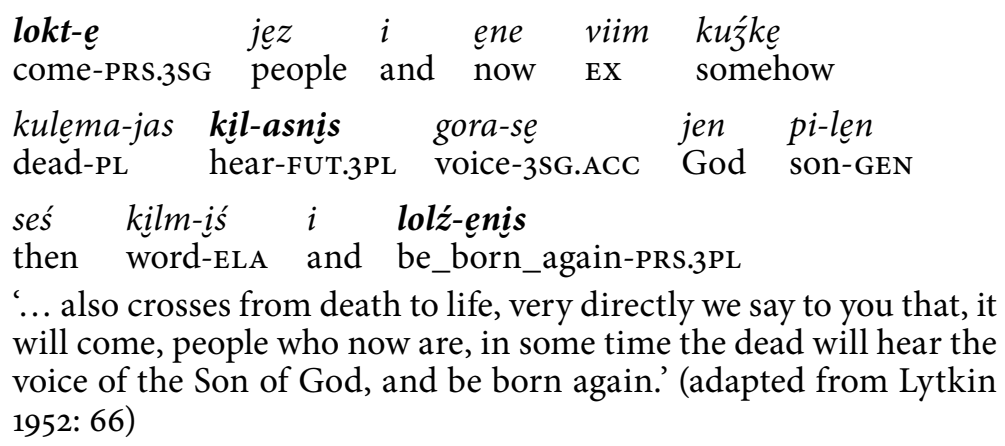

The translation is the authors' interpretation of these lines, based on the Old Komi text and the different existing translations. If we then take the contemporary Standard Komi version of the same fragment, presented in (27), we see that the tense marking is very different and is reminiscent of 
the tense marking in the English and Russian versions of the text. The time that will come is marked with the Standard Komi future tense, while the background information is given in the past tense. This can be compared to the variation in tense use in narratives that we examined in Section 5.5.

(27) [...] но кулӧмсьыс сійӧ вуджис нин олӧмас. Веськыда, веськыда висьтала тіянлы: воас кад да воис нин, кор кулӧмаяс кыласны Ен Пилысь гӧлӧс шысӧ. Сэки Сійӧс кылысьяс ловзясны.

\begin{tabular}{llllll} 
no kulem-śis & sije & vuž-is & ńin & \multicolumn{1}{c}{ olem-as. } \\
and death-3SG.ELA & 3SG & cross-PST.3SG & already & life-3SG.ILL \\
veśkida, veśkida & viśtal-a & tijanlí: & vo-as & kad \\
directly directly & say-PRS.1SG & 2PL.DAT & come-FUt.3SG & time
\end{tabular}
da vo-is ńin, kor kulema-jas kill-asni and come-PST.3Sg already when dead-PL hear-FUT.3PL jen pi-liśs gêles ši-se. seki sijes God son-ABL voice sound-3SG.ACC then 3SG.ACC

killiś-jas loví-asni

listener-PL born_again-FUT.3PL '[...] and from death he turned already to life. Truly, truly I say to you: the time will come, and has already come, when the dead will hear the son of God's voice. Then those who hear it will be born again.' (The New Testament in Komi-Zyrian language 2013: Иоан серти бур юӧр 5:24-25)

Although this is an isolated comparison, we think it provides a relatively good picture of the differences between the Udora dialect and Standard Komi when it comes to the use of these morphemes. Based on our intuition, the contemporary Bible translation reflects the way many contemporary Komi texts would express these tense distinctions. We can even compare the temporal sequence in it to Example (2) in this study, where the future tense is used to refer into an event, i.e. Vladimir being called a fool, that is presumed to occur later. However, we feel that these examples support the idea that the choice of third-person morpheme must have been conditioned at an earlier historical stage by the lexical aspect of individual verbs, possibly so that one of the morphemes was reserved for a small group of intransitive verbs, and that eventually this has come to express a more temporal sequence of events elsewhere in Komi. 


\section{Conclusion}

As we have demonstrated in our study, rather than displaying distinct present and future tenses, the Udora dialect of Zyrian Komi has one undifferentiated non-past tense. The morphemes that correspond to the Standard Komi present and future tenses are used in the dialect to distinguish two groups of verbs that differ in their lexical aspect. When the verbs are derived in ways that modify their lexical aspect, the conjugation type also changes in a predictable manner. The aspectual properties of verbs belonging to the $-e$-conjugation are connected to telicity, expressing temporal continuity and boundedness. Additionally, various process verbs and verbs of vocalisation belong to the - $e$ - conjugation, but due to their small number in the corpus, their exact properties have not been analysed here in detail. All frequent transitive verbs and approximately half of all intransitive verbs occur with -as-, which can be considered the most common third-person marker in the non-past tense in the Udora dialect.

We have described the historical background of the Udora dialect and shown that the process we encounter here has strong parallels in Old Komi. This fits well with the wider historical context of the Northern Zyrian dialects, a group that includes both Old Komi and Udora. This connection has been proposed several times before, but we hope that our investigation will serve to clarify the situation and lead to further dialectological research covering a wider range of varieties.

From the point of view of derivational morphology, we can distinguish several active processes influencing the selection of conjugation type. Causative derivations make verbs transitive, which shifts the derived verbs into the -as- conjugation type following the Udora system. Momentaneous verbs, which must be considered temporally bound, also occur principally with -as-. When it comes to verbs derived using the polysemous derivational morpheme $-\hat{s}^{-}$, the conjugation type changes in either direction in a predictable manner, depending on the type of derivation that is created.

One occasion in the Udora dialect where the two conjugation types show tense-like properties is in the tense structure of narratives, where the background information in a story is given in one of the past tenses, and the forms that correspond to the standard Komi present and future tenses are used in longer intervals of text. This use appears to override the lexical demands for a verb to fall into a specific conjugation type, thereby contributing to the variation we see in the corpus. We compare this use to historical narrative tense reported in other Komi dialects and propose that 
there could be a connection between the Udora system, this kind of tenselike usage in the narratives, and the fully functional present-future opposition that has been described in Standard Komi and the other dialects. We believe that there is still more to investigate with regard to how the tenses are used in different Komi varieties, but we hope that our contribution provides a clearer picture of the situation in the Udora dialect and the Northern Zyrian dialects more generally.

We have combined archival materials, published texts and contemporary recordings to create a collection of Udora texts that spans the entire 2oth century. The example sentences are available in the online appendix to this study and are also archived in the Udora Komi collection maintained in the Language Bank of Finland. We hope that this will allow for further verification, comparison and extension of this work whenever new material becomes available. Although numerous open questions remain concerning the verbal morphology of Komi and the Permic languages more broadly, we hope that the findings of our research offer new perspectives and directions for further work.

\section{Acknowledgements}

We would like to thank especially all the native Komi speakers whom we have had the possibility to work with, particularly Yana Sazhina and Nina Pigulina, who have welcomed us to their home village of S'ordla. We would also like to thank the team who collaborated with us during our fieldwork in Udora: Tristan Hamel, Anastasia Hamel, Timo Rantakaulio and Galina Misharina. Niko Partanen's research was carried out as part of the Kone Foundation-funded research project 'Language Documentation Meets Language Technology: The Next Step in the Description of Komi'. Our earlier work on the Udora dialect has also received funding from the Kone Foundation and the Academy of Finland's MinorEuRus project. We also want to thank the anonymous referees and the editors of the journal for their valuable comments on the manuscript.

\section{Nonstandard abbreviations used in glosses}

$\begin{array}{llll}\text { APPR } & \text { approximative } & \text { EX } & \text { existential predicate } \\ \text { CMP } & \text { comparative } & \text { FOC } & \text { focus particle } \\ \text { CNG } & \text { connegative } & \text { PST2 } & \text { second past } \\ \text { CVB.SIM } & \text { simultaneous converb } & \text { PROL } & \text { prolative } \\ \text { EGR } & \text { egressive } & \text { Q } & \text { question particle }\end{array}$




\section{References}

Aikio = Luobbal Sámmol Sámmol Ánte (Ante Aikio). (Forthcoming). ProtoUralic. In Bakró-Nagy, Marianne \& Laakso, Johanna \& Skribnik, Elena (eds.), The Oxford guide to the Uralic languages. Oxford: Oxford University Press.

BAKer, RoBIN W. 1983. Komi Zyryan's second past tense. Finnisch-Ugrische Forschungen 45. 69-81.

Bakró-Nagy, Marianne \& Laakso, Johanna \& Skribnik, Elena. 2020. As we say it in Finno-Ugric. Some thoughts on making Uralic language studies more accessible to outsiders. In Holopainen, Sampsa \& Kuokkala, Juha \& Saarikivi, Janne \& Virtanen, Susanna (eds.), Ёмас сымыьу нэ̄кве ворртур ӭтпост самын патум. Scripta miscellanea in honorem Ulla-Maija Forsberg (Mémoires de la Société Finno-Ougrienne 275), 27-41. Helsinki: Finno-Ugrian Society. https://doi.org/10.33341/sus.11.1

Bartens, Raija. 200o. Permiläiskielten rakenne ja kehitys (Mémoires de la Société Finno-Ougrienne 238). Helsinki: Société Finno-Ougrienne.

Beznosikova et al. = Безносикова, Л. М. \& Айбабина, Е. А. \& Забоева, Н. К. \& Коснырева, Р. И. 2012. Коми сёрнисикаса кывчукӧр. Словарь диалектов

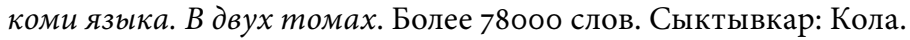

Biblia = Святое писание. Библия. Книги Священного Писания Ветхого и Нового Завета. Синодальный перевод. Русский Паломник, 2010.

Comrie, Bernard. 1976. Aspect: An introduction to the study of verbal aspect and related problems (Cambridge Textbooks in Linguistics). Cambridge: Cambridge University Press.

Croft, William. 2012. Verbs: Aspect and causal structure. Oxford: Oxford University Press.

Csúcs, SÁndoR. 2005. Die Rekonstruktion der permischen Grundsprache (Bibliotheca Uralica 13). Budapest: Akadémiai Kiadó.

Cypanov = Цыпанов, Е. А. 2005. Грамматические категории глагола в коми языке. Сыктывкар: Институт языка, литературы и истории Коми НЦ УpO PAH.

Cypanov \& Leinonen = Цыпанов, Евгений \& Лейнонен, Марья. 2009. Эвиденциальность в коми языке (на материале модального перфекта). Linguistica Uralica XLV(1). 23-35.

Dahl, Östen. 1985. Tense and Aspect Systems. Oxford: Basil Blackwell.

Dixon, Robert M. W. 2010. Basic linguistic theory. Volume 1: Methodology. Oxford: Oxford University Press.

Federal State Statistics Service, Russia = Федеральная служба государственный статистики. 2010. База данных показателей муниципальных образования. Республика Коми. Национальный состав населения. https://gks.ru/dbscripts/munst/munst87 (Accessed 3.8.2021.)

Fedjunëva et al. = Федюнёва, Г.В. \& Некрасова, Г. \& Лудыкова, В. \& Цыпанов, Е. \& Попова, Э. 2ооо. Ӧнія коми кыв: Морфология. (Edited by Г. В. Федюнёва.) Сыктывкар: Коми небӧг лэдзанін.

FILIP, HanA. 2012. Lexical aspect. In Binnick, Robert I. (ed.), The Oxford handbook of tense and aspect, 721-751. Oxford: Oxford University Press. 
Fludernik, MoniKa. 1991. The historical present tense yet again: Tense switching and narrative dynamics in oral and quasi-oral storytelling. Text 11(3). 365-397.

Fokos-Fuchs, Dávid Rafael. 1916. Zürjén szövegek. Budapest: Magyar Tudományos Akadémia.

Fokos-Fuchs, DÁvid RAFAEL. 1959. Syrjänisches Wörterbuch: Über 20 ooo syrjänische Wörter in genauer Umschrift und mit deutscher Übersetzung, nebst Angabe ihrer Formen, Verbreitung und Anwendungen. Anschliessend ein deutsches Wortregister. Budapest: Akadémiai kiadó.

HÄмÄLÄINEN, MikA. 2019. UralicNLP: An NLP Library for Uralic Languages. Journal of Open Source Software 4(37). 1345. https://doi.org/10.21105/joss.01345.

The Holy Bible. New International Version. Biblica, Inc. 2011. https://biblehub.com.

Hopper, Paul J. \& Thompson, Sandra A. 1980. Transitivity in grammar and discourse. Language 56(2). 251-299.

ITKONEN, ERKKI. 1958. Komin tasavallan kielitieteeseen tutustumassa. Virittäjä 62(1). 66-66.

KLumPP, Gerson. 2008. Differentielle Objektmarkierung \& Informationsstruktur in Dialekten des Komi. Habilitation. München: Fakultät für Sprach- und Literaturwissenschaften der Ludwig-Maximilians-Universität München.

Leinonen, Marja \& Vilkuna, Maria. 200o. Past tenses in Permian languages. In Dahl, Östen (ed.), Tense and aspect in the languages of Europe, 495-514. Berlin: Mouton de Gruyter.

LJAŠEV = Ляшев, B. А. 1977. Некоторые дистинктивные признаки северного нуль-элового ареала коми языка. Советское финно-угроведение 13(2). 119-123.

LJAŠEV = Ляшев, B. A. 1980. Диалектное членение древнекоми языка. Сыктывкар: Академия наук СССР Коми филиал.

LYTкіN = Лыткин, В. И. 1952. Древнепермский язык: Чтение текстов, грамматика, словарь. Москва: Издательство академия наук СССР.

LytкіN = Лыткин, В. И. (ed.) 1955. Современный коми язык. Часть первая. Сыктывкар: Коми книжное издательство.

LYTKIN = Лыткин, В. И. 1961. К вопросу о конечной гласной основы глаголов настоящего времени в финно-угорских языках. Bопросы языка, литературы и фольклора. Труды, выпуск 15, 49-57. Йошкар-Ола: Марийский научно-исследовательский институт языка, литературы и истории.

LYTкіN = Лыткин, В. И. 1962. Коми-пермяикий язык: введение, фонетика, лексика и морфология. Кудымкар: Коми-пермяцкое книжное издательство.

LYTKIN = LITKIN, VASZILIJ. 1969. A finnugor alapnyelv szóvégi magánhangzóiról [Über den Auslautvokale der finnougrischen Grundsprache]. Nyelvtudományi Közlemények 71. 95-99.

LYTKIN = Лыткин, B. И. 1977a. Зачатки объектного спряжения в коми языка. Советское финно-угроведение 13(4). 280-283.

LYtкіN = Лыткин, В. И. 1977b. Коми кывлӧн историческӧй морфология. Пермь \& Сыктывкар: А. М. Горький нима трудӧвӧй Краснӧй Знамя ордена Пермса государсвеннӧй университет \& СССР-лы 50-во нима Сыктывкарса государственнӧй университет.

Matveev = Матвеев, Александр М. 1958. Невеста. Войвыв кодзув 2. 47-50. 
Neкrasova = Некрасова, Г. А. 2ооо. Коми кывлӧн историческӧй фонетика. Сыктывкар: Россияса наукаяслӧн академия.

The New Testament in Komi-Zyrian language. 2013. Institute for Bible Translation. http: //finugorbib.com/bible/komi_zyrian.

Partanen, Niko. 2021. Old Komi: Digital Edition. https:/github.com/langdoc/ writtenkomi-corpus-old-komi.

PonARJADOv = Понарядов, Вадим. 2004. О глагольных окончаниях -ӧ и -ас в удорском диалекте. In Вопросы коми диалектологии (Труды Института языка, литературы и истории Коми НЦ УрО РАН. Вып. 65), 104-112. Сыктывкар: Институт языка, литературы и истории Коми НЦ УрО РАН.

Popova \& SAžınA = Попова, Р. П. \& Сажина, С. А. 2014. Фонетические и морфологические особенности коми диалектов (сравнительный аспект исследования). Сыктывкар: Издательство СыктГУ.

RÉDEI, KAROLY. 1989. Über die finnougrische Konjugation unter besonderer Berücksichtigung der ungarischen Personalsuffixe. Journal de la Société FinnoOugrienne 82. 93-209.

RUETER = Рютер, Джек M. 200о. Хельсинкиса университетын кыв туялысь Ижкарын перымса кывъяс симпозиум вылын лыддьӧмтор. In Пермистика: Проблемы синхронии и диахронии пермских языков и их диалектов (Пермистика 6), 154-158. Ижевск: Удмуртский университет.

SAVEL'Eva = Савельева, Э. А. (ed.) 1997. Историко-культурный атлас Республики Коми. Москва: Дрофа \& ДиК.

SAŽINA = Сажина, С. А. 2014. Исторические условия формирования коми-зырянских диалектов. In Зайцева, Н. Г. \& Муллонен, И. И. (eds.), V Всероссийская конферениия финно-угроведов «Финно-угорские языки и культуры в соииокультурном ландшафте России». Материаль, 81-83. Петрозаводск: Институт языка, литературы и истории КарНЦ РАН.

SCHIFFrin, DeborAh. 1981. Tense variation in narrative. Language 57(1). 45-62.

SEREBRENNIKOV = Серебренников, Б. А. 1956. Из истории образования глагольных времен в коми языке. Историко-филологический сборник. Выпуск 3, 57-69. Сыктывкар: Академии наук СССР Коми филиал.

Serebrennikov = Серебренников, Б. А. 1960. Категории времени и вида в финно-угорскихязыкахпермской и волжской групп. Москва: Издательство Академии наук СССР.

Serebrennikov = Серебренников, Б. А. 1963. Историческая морфологииа пермских языков. Москва: Издательство Академии наук СССР.

SKNA = Suomen kielen nauhoitearkisto (Tape Archive of the Finnish Language), Institute for the Languages of Finland.

Sidorov = Сидоров, А. С. 1930. Характеристика удорского (вашского) говора. In Лыткин, В. И. (ed.), Сборник комиссии по собиранию словаря и изучению диалектов коми языка. Выпуск 1, 49-56. Сыктывкар: Комиссия по собиранию Коми словаря при Обществе Изучение Коми края.

Sidorov = Сидоров, А. С. 1962. Новые памятники древнекоми письменности (с комментариями, подстрочными примечаниями и заключением В. И. Лыткина). Вопросы финно-угорского языкознания, 178-211. Ленинград: Издательство Академии наук СССР. 
SoRvačEVA = Сорвачева, В. А. 1952. Некоторые фонетические и морфологические особенности верхне-вашского говора удорского диалекта. In Лингвистический сборник. Серия тингвистическая. Выпуск 2, 37-48. Сыктывкар: Коми Государственное Издательство.

SorvačEva \& Beznosikova = Сорвачева, В. А. \& Безносикова, Л. М. 1990. Удорский диалект коми языка. Москва: Наука.

Stipa, Günter Johannes. 1962. Käynti syrjäänien tieteen tyyssijassa. Virittäjä 66(1). 61-68.

Todesk, TRIIN. 2015. The verbal augmentative and the inherent properties of verbs in Komi. Linguistica Uralica 51(1). 28-43.

TuRkin = Туркин, А. И. 1984. О двух гидронимических формантах в коми топонимии. In Вопросы тексикологии и словообразования коми языка (Труды Института ЯЛИ Коми НЦ УрО РАН 32), 177-182. Сыктывкар: Академия наук СССР Коми филиал.

UотіlA, T. E. 1938. Syrjänische Chrestomathie: mit grammatikalischem Abriss und etymologischem Wörterverzeichnis (Hilfsmittel für das Studium der finnischugrischen Sprachen VI). Helsinki: Société Finno-Ougrienne.

Uotila, T. E. 1989. Syrjänische Texte. Band III. Komi-Syrjänisch: Luza-Letka-, Ober-Sysola-, Mittel-Sysola-, Prisyktyvkar-, Unter-Vyčegda- und UdoraDialekte. Gesammelt von T.E. Uotila. Übersetzt und herausgegeben von Paula Kokkonen (Mémoires de la Société Finno-Ougrienne 202). Helsinki: Société Finno-Ougrienne.

Vahros-Pertamo, MuUsa. 1963. Syrjäänien asuinseuduilla. Virittäjä 67(1). 77-85. VÁszolyi-VAsse, E. 1999. Syrjaenica: Narratives, folklore and folk poetry from eight dialects of Komi. Upper Izhma, Lower Ob, Kanin Peninsula, Upper Jusva, Middle Inva, Udora. Volume 1 (Specimina Sibirica 15). Szombathely: Seminar für Uralische Philologie der Berzsenyi Hochschule.

Wichmann, YRJö JoosePPI. 1916. Syrjänische volksdichtung (Mémoires de la Société Finno-Ougrienne 38). Helsinki: Société Finno-Ougrienne.

Wiedemann, FERDINAND JoHANN. 1884. Grammatik der syrjänischen Sprache mit Berückichtigung ihrer Dialekte und des Wotjakischen. St. Petersburg: Kaiserlichen Akademie der Wissenschaften.

ŽEREBCOV = Жеребцов, Л. Н. 1972. Хозяйство, культура и быт удорских коми в XVIII - начале XX в. Москва: Наука.

ŽılinA = Жилина, Т. И. 1975. Верхнесысольский диалект коми языка. Москва: Наука.

Žılina \& SoRvačEva = Жилина, Т. И. \& Сорвачева, В. А. (eds.) 1971. Образцьь коми-зырянской речи. Сыктывкар: Академия наук СССР Коми филиал.

\section{Appendix}

The online appendix "Tense and Aspect in Udora Komi" is available at https://doi.org/10.33339/fuf.97371. 